\title{
Analisis Bornedal atas Pandangan Nietzsche tentang \\ Pembentukan Nilai Baik dan Jahat
}

\author{
Y. Adi Wiyanto \\ adiandes@yahoo.com
}

\begin{abstract}
Abstrak
Nietzsche berpandangan bahwa pembentukan nilai baik dan nilai jahat dapat ditelusuri dari perbedaan kelas sosial di peradaban kuno, khususnya Yunani, yaitu antara kelas atas (kaum tuan) dan kelas bawah bawah (kaum budak). Dari perbedaan kelas tersebut, Nietzsche mendefinisikan nilai baik sebagai semua ciri dan sifat dalam kaum tuan, sedangkan nilai buruk adalah semua ciri dan sifat dalam kaum budak. Adapun nilai jahat adalah hasil pembalikan nilai baik dalam kaum tuan yang dilakukan oleh kaum budak. Pembalikan nilai ini dapat terjadi karena ressentiment. Ressentiment ini juga menghasilkan nilai baik bagi kaum budak. Bornedal menganalisis bahwa proyek filsafat Nietzsche dalam pembentukan nilai baik dan nilai jahat tersebut terlalu menyederhanakan proses mental, dorongan, dan penilaian. Menurut Bornedal, oposisi antara baik dan jahat tidak pernah stabil, definisi baik dan jahat saling melengkapi, serta baik dan jahat merupakan oposisi relatif yang terkait dengan pembentukan makna baik dan jahat itu sendiri. Selain itu, baik dan jahat juga saling terkait dan tidak dapat dipisahkan.
\end{abstract}

Keywords: Moral, baik, buruk, jahat, ressentiment, moral tuan, moral budak.

\begin{abstract}
Nietzsche demonstrates that the formation of good and evil value can be traced from the distinction in social class in ancient civilizations, especially Greece, namely between the upper class (the master) and the underclass (the slave). From this distinction, Nietzsche defines good value as all traits belonging to the master. Bad value is otherwise all traits belonging to the slave. The evil value emerges from the good value inversion in the master carried out by the slave. The inverted value takes place as an act of ressentiment. The slave lodges this ressentiment to mould own good value. Bornedal analyses that Nietzsche's notion on good and evil opposition simplifies inner-mental
\end{abstract}


processes, drives and valuations. The opposition between good and evil is unstable and never that solid. In good and evil opposition, the two positions are complementary. They are mutually dependent on each other for their definition. The good and evil are hence such relative opposition pertaining to the formation of good and evil meaning on themselves. In addition, good and evil are also interrelated and cannot be separated.

Keywords: Moral, good, bad, evil, ressentiment, master morality, slave morality.

Y. Adi Wiyanto adalah pelaku filsafat, mahasiswa Pascasarjana STF Driyarkara.

\section{Pendahuluan}

Proyek penelitian Peter Bornedal adalah tentang mental karena di sinilah filsuf imoral pewarta kematian Tuhan, Friedrich Nietzsche, melakukan semacam "lompatan" nilai. Dalam konteks munculnya nilai jahat, misalnya, Nietzsche menggunakan "budak" untuk membalik nilai baik menjadi nilai jahat. Secara keseluruhan, proyek penelitian Bornedal beririsan dengan psikologi ataupun psikoanalisis.

Ia mengawali proyek penelitiannya dengan bertitik tolak dari aspek permukaan dan kedalaman. Dari aspek permukaan dan kedalaman itu, Bornedal kemudian mengupas dimensi mental-psikologis dalam dialektika wanita dan lelaki. Dalam dialektika ini, Bornedal menemukan dan memaparkan fakultas mental, antara lain, yaitu kesadaran-ketaksadaran, insting, dan represi.

Bornedal kemudian beranjak ke dimensi mental daya atau energi yang disebut dengan kateksis. Dalam konfigurasi moral tuan dan moral budak, kateksis akan berubah seturut tipe subyek, yakni menjadi hiperkateksis atau dekateksis. Setelah itu, Bornedal mengupas dimensi mental pelupaan dan ingatan yang memengaruhi subyek berhadapan dengan keadilan dan hukum.

Terkait dengan pelupaan dan ingatan itu, Bornedal selanjutnya berbicara tentang pembentukan rasa bersalah. Di sini, Bornedal memaparkan dimensi mental agresi yang termanifestasikan dalam protosadisme dan protomasokhisme. Dari analisis mental dalam moral tuan dan moral budak tersebut, Bornedal kemudian memberikan pandangan tentang baik dan jahat.

\section{Permukaan dan Kedalaman}


Bornedal menitikberatkan penelitiannya pada analisis tentang konfigurasi moral tuan dan moral budak. Dengan konfigurasi, Bornedal bermaksud menjelaskan perbedaan formasi jiwa (psyche) dari dua tipe moral itu. Moral budak menggambarkan formasi mental, sedangkan moral tuan menggambarkan formasi yang lain. Fokus penelitian Bornedal adalah pada dimensi mental ini.

Bornedal menggunakan istilah konfigurasi asertif untuk menjelaskan tipe moral tuan dan konfigurasi agresif untuk tipe moral budak. ${ }^{1}$ Dengan konfigurasi, Bornedal ingin menunjukkan perbedaan formasi jiwa (psyche). ${ }^{2}$ Moral budak merujuk kepada formasi mental, sedangkan moral tuan merujuk kepada formasi yang lain. ${ }^{3}$

Moral tuan, menurut Bornedal, ${ }^{4}$ dicirikan dengan permukaan. Disebut permukaan karena sang tuan tidak akan menyentuh inti dalam dirinya. Ketika tidak menyentuh inti dalam dirinya, ia menyentuh ketaksadarannya. Ia senantiasa di permukaan untuk merespons hakikat dirinya. Dengan kata lain, dalam bertindak, manusia tuan bertindak begitu saja tanpa memikirkan tindakan yang ia lakukan karena tindakan tersebut merupakan wujud pengejawantahan moral tuan yang melekat dalam dirinya. Sebagai contoh, ketika berkendara, manusia tuan secara otomatis (tanpa disadari) menghentikan laju kendaraannya ketika lampu lalu lintas menyala merah dan baru akan menjalankan kendaraannya ketika lampu lalu lintas menyala hijau.

Bornedal $^{5}$ mengatakan bahwa apa yang dilakukan Nietzsche dengan menjelaskan asal usul baik dan buruk secara etimologis merupakan salah satu ciri dari permukaan. Menurut Nietzsche, yang disebut baik adalah apa saja yang tampak atau terlihat baik. Di peradaban Yunani kuno, penilaian antara yang disebut baik dan buruk sudah muncul dalam masyarakat berdasarkan perbedaan kelas sosial masyarakat waktu itu, yaitu antara kelas atas (kaum tuan, ningrat, bangsawan, penguasa, aristokrat) dan kelas bawah (kaum budak, rakyat jelata, masyarakat biasa). Dalam On the Genealogy of Morals (GM) I §4, Nietzsche mengatakan:

-Petunjuk yang tepat diberikan kepadaku dengan sebuah pertanyaan: secara etimologis, apa arti 'baik' dalam bermacam-macam bahasa? Aku menemukan bahwa pembentukan kata 'baik' berasal dari transformasi konsep yang sama-bahwa di masyarakat mana pun 'ningrat', 'aristokrat' adalah konsep dasar bagaimana kata 'baik' yang menggambarkan ciri, sifat, dan karakter kelas 'aristokrat', 'ningrat', 'atas', 
'terhormat' berkembang: ini paralel dengan perkembangan ciri, sifat, dan karakter kelas

'biasa', 'kawanan', 'rendah' yang akhirnya membentuk konsep 'buruk' ....

Nietzsche mengatakan bahwa mereka yang termasuk kelas atas, antara lain, adalah para prajurit, orang yang memiliki pengaruh dan kekuasaan, atau yang bekerja bersama mengatur masyarakat dari aspek sosial, politik, dan hukum. Status sebagai masyarakat kelas atas mereka dapatkan dari kelahiran, perkawinan, ataupun keberhasilan dalam bidang militer atau perdagangan. ${ }^{7}$

Masyarakat kelas atas atau kaum tuan ini memiliki ciri-ciri, sifat, dan karakter seperti baik, bijaksana, kaya, berani, kuat, berkuasa, dan bahagia. ${ }^{8}$ Mereka bertindak secara spontan dan tindakan mereka muncul dari inisiatif pribadi. Mereka sendiri yang menciptakan sekaligus menggerakkan suatu tindakan. Maka, tindakan kaum tuan bersifat akfif, bukan reaktif. Jika kaum tuan ingin memburu lawan atau musuh, tindakan mereka semata-mata untuk mengafirmasi diri. Kaum tuan menginginkan musuh yang setara karena jika melawan musuh yang tidak setara, apalagi kaum lemah, hal itu hanya merendahkan derajat mereka sendiri. ${ }^{9}$

Kepada sesama kaum tuan, kaum tuan menunjukkan pemikiran yang matang, penguasaan diri, kesetiaan, kebanggaan, dan rasa pertemanan. Namun, terhadap orang lain, orang asing, mereka akan kembali menjadi "monster pemangsa". ${ }^{10}$ Ini bukan berarti kaum tuan membenci orang asing. Kaum tuan bertindak seperti itu karena kodrat mereka memang seperti itu. ${ }^{11}$ Kaum tuan merasa tidak bersalah dan paling superior. Mereka kemudian menciptakan nilai baik. ${ }^{12}$

Yang "baik" merujuk kepada diri mereka sendiri, yaitu kaum tuan, yang kuat, yang berkedudukan tinggi dan berpikir tinggi, dan yang bertindak baik. Mereka adalah kelas atas yang berbeda dengan mereka yang disebut kelas bawah, yang berpikiran rendah, dan rakyat biasa. Adalah pathos of distance yang membuat mereka mampu menciptakan nilai-nilai seperti itu: mereka tidak peduli apa itu kegunaan! (GM I §2). ${ }^{13}$

Nietzsche melihat bahwa kata-kata yang bermakna "positif” lahir dari penggambaran ciri, sifat, dan karakter kaum tuan itu. Nietzsche ${ }^{14}$ memberi contoh kata esthlos yang berarti 'mulia', 'ningrat' dan kata agathos yang berarti 'baik', 'bagus'. Kemudian muncul kaloi kagathoi yang berarti 'kaum baik', 'kaum ningrat', 'kaum tuan'. ${ }^{15}$ Kaloi kagathoi adalah kaum yang sehat, kuat, dan tahan banting. Mereka mengasah kekuatan dengan bertualang, berburu, berperang, dan berkompetisi dalam olah fisik dan ketangkasan atau atletik. ${ }^{16}$ 
Menurut Bornedal, ${ }^{17}$ asal usul yang baik ini tidak muncul dari konotasi etis-psikologis, demikian juga dengan yang disebut buruk. Nietzsche mengatakan bahwa yang buruk merujuk kepada masyarakat biasa, kawanan, kelas bawah. Masyarakat kelas bawah atau kaum budak memiliki ciri-ciri, sifat, dan karakter seperti buruk, jelek, lemah, pengecut, dan miskin. Untuk menyebut mereka, Nietzsche menggunakan kata kakos yang berarti 'buruk', 'jelek' dan deilos yang berarti 'pengecut', 'tak berguna'. Lalu muncul kata demos yang berarti 'rakyat banyak', 'kawanan', dan hoi polloi yang berarti 'kaum orang kebanyakan'. ${ }^{18}$ Adapun kata Jerman, schelcht (buruk) yang secara etimologis berasal dari kata schlicht (sederhana) juga mengacu kepada masyarakat biasa.

Contoh paling jelas adalah kata Jerman "schlecht" (buruk): yang identik dengan kata "schlicht" (datar, sederhana)—bandingkan dengan "schlechtweg", "schlechterdings" (secara sederhana atau menurun) - yang merujuk kepada kaum rendah, masyarakat biasa, dan tanpa melihat ke samping, mereka adalah lawan kaum tuan (GM I §4). ${ }^{19}$

Nietzsche kemudian menggunakan pembedaan antara kaum tuan dan kaum budak tersebut untuk mendefinisikan nilai baik dan nilai buruk. Semua ciri, sifat, dan karakter yang melekat pada kaum tuan disebut sebagai nilai baik. ${ }^{20}$ Namun, moral tuan, menurut Nietzsche, tidak merujuk ciri, sifat, dan karakter yang disebut nilai baik itu. Ciri, sifat, dan karakter yang disebut nilai baik itu sudah melekat pada mereka yang memiliki moral tuan. Moral tuan lebih menunjukkan identitas diri dan afirmasi diri. ${ }^{21}$ Artinya, mereka disebut tuan bukan karena raja atau penguasa, melainkan karena "ketuan-an" mereka. Seseorang disebut berani, kuat, dan jujur karena dia memang berani, kuat, dan jujur. Maka, orang miskin juga dapat disebut tuan karena memiliki moral tuan dalam dirinya, sedangkan orang kaya tidak dapat disebut tuan jika tidak memiliki moral tuan dalam dirinya. ${ }^{22}$

Adapun semua ciri, sifat, dan karakter yang melekat pada kaum budak disebut sebagai nilai buruk. ${ }^{23}$ Siapa pun yang bukan termasuk kaum tuan alias "yang lain” dianggap buruk. Kaum tuan menyadari bahwa ada kelompok lain yang miskin, lemah, rendah, atau budak. Namun, keberadaan mereka tidak begitu memengaruhi kaum tuan. Ketika kaum tuan mengatakan bahwa diri mereka adalah yang baik, kaum tuan kemudian menunjuk kaum budak sebagai yang buruk. Namun, menurut Nietzsche, nilai baik dalam kaum tuan tidak muncul dari dominasi mereka terhadap kaum budak. Kaum tuan pada dirinya sendiri baik adanya. Jika ada kelompok lain yang dianggap buruk, kaum tuan memandang mereka biasa saja tanpa preferensi apa pun. Dengan kata lain, kaum tuan menganggap yang buruk hanya sebagai kesan atau tambahan (afterthought). ${ }^{24}$ 
Bornedal $^{25}$ mengatakan bahwa nilai baik dan buruk itu terbentuk karena menerima semacam "roh". Sebagai suatu nilai, kata baik dan buruk itu kemudian tidak lagi di permukaan, tetapi masuk ke dalam esensi tersembunyi. Yang disebut baik lalu mengacu kepada semua tindakan tepa salira, tenggang rasa, tidak mementingkan diri sendiri. Dalam terminologi "kehendak baik" Kant, itulah yang disebut "baik pada dirinya sendiri" dan bukan "baik sebagai yang tampak".

Kaum budak pada akhirnya memberontak terhadap kaum tuan. ${ }^{26}$ Dengan pemberontakan itu, kaum budak melakukan pembalikan nilai. ${ }^{27}$ Nilai-nilai tuan yang disebut baik, seperti kuat, bijaksana, jujur, dan setia, dibalik dan didevaluasi menjadi nilai jahat. Adapun nilai-nilai budak, seperti lemah, pengecut, dan pasif, direpresi dan disublimasi menjadi nilai baik, seperti rendah hati, sabar, dan belas kasih. Nietzsche menyebut nilai-nilai hasil pembalikan ini sebagai moral budak. ${ }^{28}$

Kebalikan dari pembalikan nilai moral budak ialah pembalikan nilai moral tuan: moral tuan bekerja dan bergerak secara spontan, dia mencari lawan hanya untuk mengatakan "ya" kepada dirinya sendiri disertai rasa syukur dan gembira-pandangan negatif, seperti "rendah", "biasa", "buruk", hanyalah semacam kesan, gambaran kontras dan buram yang terkait dengan pandangan positif yang terus dipenuhi melalui kehidupan dan gairah: "kami ningrat", "kami orang baik", "kami cantik", "kami bahagia”! Jika pembalikan moral tuan melukai kehidupan dan berdosa terhadapnya, itu terjadi secara relatif di kalangan yang tidak cukup dikenal, yaitu di kalangan yang dengan teguh membela pengetahuan mereka: di beberapa kasus, pembalikan nilai tuan kadang salah memahami kalangan pencemooh, yaitu masyarakat biasa, kaum bawah; (GM I §10).

Nietzsche mengatakan bahwa di peradaban Yunani kuno, yang disebut kaum budak merujuk kepada masyarakat kelas bawah. Mereka, antara lain, adalah tukang sepatu, pandai besi, tukang batu, petani, dan pendayung kapal. Di peradaban Yunani dan Romawi, mereka adalah para pedagang asongan, nelayan, gelandangan, kaum perempuan, dan budak. Singkatnya, mereka adalah kaum miskin dan tertindas. $^{29}$

Maka, menurut Nietzsche, tidak mengherankan jika kaum budak merasa tidak puas dengan status mereka dan dampak sosial, politik, eksistensial, bahkan psikologis dari status yang mereka sandang itu. Mereka tidak puas, tetapi tidak memiliki sarana untuk memperbaiki nasib mereka. Karena tidak mampu mewujudkan rasa ketidakpuasan itu, mereka lantas menginternalisasikannya. Ketidakpuasan 
dan ketidakmampuan itu akhirnya memancarkan "asap kemarahan” yang bisa muncul begitu kuat, bahkan menyenangkan sehingga membuahkan kreativitas yang mengerikan. ${ }^{30}$

Nietzsche mengatakan bahwa kaum budak awalnya menyerukan jalan damai berupa resolusi politik atau aksi militer karena jumlah mereka lebih banyak jika dibandingkan dengan jumlah kaum tuan. Namun, kaum budak menyadari bahwa pemberontakan dengan kekuatan fisik, seperti militer, hanya akan mendatangkan petaka karena kaum budak tidak memiliki kekuatan alias lemah. Maka, pemberontakan yang dapat mereka lakukan ialah dengan cara moral-psikologis. ${ }^{31}$

Pembalikan moral tuan menjadi moral budak ini, menurut Nietzsche, merupakan "kemenangan" moral. Kaum budak membalik nilai-nilai kaum tuan menjadi nilai-nilai kaum budak, kemudian menyambut dan menerima nilai-nilai hasil pembalikan itu, karena dalam pandangan mereka, mereka akan menerima imbalan berupa harapan, keselamatan, dan penebusan. ${ }^{32}$

Nietzsche memberi contoh bahwa yang dilakukan bangsa Yahudi dengan merevaluasi nilai-nilai dalam wujud balas dendam spiritual terhadap musuh dan penakluk mereka disebut sebagai pemberontakan moral budak. Peralihan dari Yunani kuno ke Yudeo-Kristiani merupakan buah pemberontakan moral budak. ${ }^{33}$ Pada akhirnya, "pemberontakan budak" membawa mereka ke panggung kemenangan sejarah dan politik. ${ }^{34}$

Menurut Nietzsche, kaum budak dapat mengubah bentuk perlawanan fisik mereka terhadap kaum tuan menjadi ganjaran berupa harapan, keselamatan, dan penebusan karena campur tangan kaum imam. Kaum imam inilah yang memimpin pemberontakan moral budak, bukan para budak. Para imam ingin menuntut balas terhadap sesama kaum tuan karena sebagai sesama kaum tuan, para imam tidak dapat menduduki posisi kaum tuan lainnya, misalnya sebagai raja atau pemimpin perang. Para imam akhirnya mengubah nilai baik yang mereka sandang untuk kepentingan mereka dan kaum budak. ${ }^{35}$

Sebagai pemimpin spiritual, kaum imam memikat kaum budak dengan iming-iming janji surga sebagai sulih atas penderitaan dan penindasan yang mereka alami. Dengan berbekal pengajaran religiometafisik berupa imortalitas personal melalui penebusan ilahi, kaum imam memperoleh buah kesetiaan moral dan dukungan dari kaum tertindas, kaum budak, kaum lemah. Kelemahan itu mereka ubah menjadi rasa benci, dendam, yang tumbuh dan berkembang secara spiritual. ${ }^{36}$ 
Rasa benci, iri, dan dendam itu oleh Nietzsche disebut sebagai ressentiment. Ressentiment inilah yang mendorong kaum budak mampu melakukan pembalikan nilai-nilai. Nietzsche menyebut ressentiment sebagai gigitan dan sengatan perasaan getir, dendam kesumat yang selalu tinggal tetap dan bergaung dalam relung jiwa. Namun, kaum budak tidak mampu mengolah ressentiment itu karena mereka lemah alias tidak memiliki kekuatan sehingga ressentiment itu akhirnya direpresi dan disublimasi. ${ }^{37}$ "Pemberontakan moral budak dimulai ketika ressentiment menjadi kreatif dan melahirkan nilai-nilai: ressentiment yang dipenuhi dendam imajiner sebagai respons atas tindakan yang ditolak..." (GM I $\S 10) .^{38}$

Dalam Human, All Too Human (HAH), Nietzsche mendasarkan ressentiment pada relasi kekuasaan antara kaum tuan dan kaum budak. Kaum tuan memiliki kekuasaan untuk menyerang balik dari sudut pandang agresivitas. Namun, dari sudut pandang kehendak baik, kaum tuan juga memiliki kekuasaan untuk memberi kembali. Dengan kata lain, kaum tuan, menurut Nietzsche, mampu melakukan pembalasan. Mereka penuh kuasa sehingga memiliki kebebasan untuk meluapkan agresivitas dan mengekspresikan hasrat mereka. ${ }^{39}$

Sebaliknya, kaum budak, Nietzsche mengatakan, tidak mampu membalas dan melawan karena mereka pada dasarnya lemah. Segala macam pembalasan hanya dapat disembunyikan, dipendam, diinternalisasikan, dan disublimasikan menjadi sesuatu yang bersifat spiritual dan psikologis sebagai ganti atas pembalasan yang tidak mampu mereka lakukan itu. Kaum budak, pada akhirnya, kalah, terpenjara, tertindas, dan dipermalukan oleh kaum tuan. Nietzsche secara jelas membedakan asal usul nilai moral berdasarkan relasi kekuasaan di antara dua kelas sosial yang berbeda itu: ${ }^{40}$

Yang disebut baik dan jahat memiliki dua hal penting dalam era prasejarah: pertama, roh suku dan ras penguasa. Dia yang memiliki kuasa untuk melakukan pembalasan, baik dibalas baik, jahat dibalas jahat, dan yang sungguh-sungguh berlatih pembalasanartinya, penuh syukur dan dendam — disebut baik; mereka yang lemah dan tidak mampu membalas disebut buruk. Sebagai orang yang baik, dia tergabung dalam yang "baik", sebuah komunitas yang mempunyai rasa memiliki satu sama lain karena semua individu di dalamnya disatukan oleh kemampuan membalas. Sebagai orang yang buruk, dia tergabung dalam yang "buruk", kawanan yang tertindas, orang-orang lemah yang tidak mempunyai rasa memiliki satu sama lain, seperti butiran pasir. Yang baik dan buruk untuk waktu yang lama sama dengan ningrat dan jelata, tuan dan budak. Di sisi lain, orang tidak menganggap musuh sebagai yang jahat: dia mampu membalas... (HAH I $\S 45){ }^{41}$ 
Nietzsche kemudian menunjukkan bahwa masyarakat Yunani dapat menjadi musuh satu dengan yang lain, tetapi dapat saling menghormati di antara mereka karena rasa hormat itu didasarkan pada kemampuan membalas yang mereka miliki. ${ }^{42}$ Nietzsche memberikan contoh Perang Troya. Dalam keseluruhan cerita di Iliad dan Odyssey/Ulysses karya Homeros, baik orang Yunani maupun orang Troya dianggap sebagai orang baik. Prajurit bahkan Homeros sendiri mendapat penghormatan dan pujian. Pada dasarnya, rasa hormat diberikan di antara mereka yang memiliki kelas sama dan ini yang membentuk moral tuan. Kaum budak tidak dihormati oleh kaum tuan karena mereka tidak mampu membalas yang jahat ataupun yang baik. Maka, terkait penilaian moral tentang yang baik dan jahat dari sudut kaum tertindas ini, Nietzsche mengatakan: ${ }^{43}$

Kemudian dalam roh yang ditindas, yang lemah (dari sudut pandang ini), setiap orang lain, entah kaum ningrat atau kaum jelata, dianggap sebagai yang bengis, kejam, licik, dan siap mereaksi. (Di kasus ini) Jahat adalah pernyataan/ungkapan/kata yang mencirikan manusia, ya, untuk makhluk hidup yang eksistensinya diandaikan, seperti tuhan, misalnya: manusia, ketuhanan dianggap sama dengan iblis, jahat. Tanda-tanda kebaikan, kebajikan, dan simpati dianggap sebagai tipu muslihat, awal determinasi yang menakutkan, singkatnya, sebagai kejahatan yang berbudi halus. Ketika seseorang memegang disposisi seperti itu, sebuah komunitas sulit terbentuk, atau paling tidak bentuk paling kasar dari komunitas; maka, di mana pun yang baik dan jahat ini memerintah, kehancuran individu, suku, dan ras mereka sudah dekat (HAH I §45). ${ }^{44}$

Dalam On the Genealogy of Morals, Nietzsche mendasarkan ressentiment pada pembedaan kelas sosial masyarakat, terutama pada pembedaan kekuatan antara kaum tuan dan kaum budak. Pada dasarnya kaum budak tidak memiliki kekuatan. Ketiadaan kekuatan inilah yang membuat ressentiment mampu bertindak sebagai panglima atas rasa iri dan dendam dalam pemberontakan moral yang dilakukan kaum budak. ${ }^{45}$

Di sisi lain, perlu diingat bahwa afek mencemooh, menghina, sebagai kelas atasdengan maksud menyalahkan kalangan pencemooh—akan jatuh dalam kepalsuan karena kebencian yang ditekan, balas dendam kaum lemah, akan melukai lawan—dalam pikiran, tentu saja... (GM I §10). ${ }^{46}$

Menurut Nietzsche, moralitas budak dimulai dengan hakikat ressentiment yang menyangkal perbuatan dan menggantinya dengan balas dendam imajiner ini. Jika moral tuan mengafirmasi hidup 
dengan mengatakan "ya", moral budak mengatakan "tidak" terhadap segala sesuatu di luar dirinya, apa saja yang berbeda dengan dirinya, apa saja yang bukan dirinya. Penidakan ini bukanlah perbuatan yang kreatif. Hakikat ressentiment adalah kebutuhan yang mengarah ke luar daripada ke dalam. Moral budak membutuhkan musuh dari luar dirinya. Mereka perlu bertindak reaktif supaya eksis. ${ }^{47}$

Sementara moral tuan mengatakan "ya" kepada kehidupan, moral budak mengatakan "tidak" kepada apa saja di "luar" dirinya, apa pun yang "berbeda" dengan dirinya, dan yang tidak terkait dengan "dirinya". Tindakan moral budak yang mengatakan "tidak" ini kreatif. Pembalikan nilai-yang secara esensial mengarah ke luar daripada ke dalam diri seseorang - adalah hakikat ressentiment: supaya eksis, moral budak selalu membutuhkan lawan dan dunia di luar dirinya; dia secara psikologis memerlukan stimulus dari luar agar bisa bertindak, — tindakan moral budak pada dasarnya reaktif...

$(\mathrm{GM} \mathrm{I} § 10) .{ }^{48}$

Bornedal $^{49}$ mengatakan bahwa kaum imam berperan membawa nilai baik masuk ke dalam esensi tersembunyi yang mengakibatkan nilai jahat muncul. Tindakan manusia akhirnya dapat ditimbang dan diukur berdasarkan tolok ukur kedalaman tersembunyi itu. Namun, manusia di permukaan yang belum menerima "roh" memiliki kapasitas untuk tidak bertindak baik ataupun jahat karena tidak ada tolok ukur untuk menimbang dan mengukur tindakan tersebut.

Menurut Bornedal, ${ }^{50}$ ada dua asumsi suatu tindakan disebut jahat. Pertama, tindakan tersebut didorong oleh kehendak jahat. Kedua, ada kebebasan. Artinya, sebelum suatu tindakan dilakukan, ada pelaku yang akan melakukan tindakan itu. Pelaku memiliki kesadaran dan tanggung jawab. Dalam diri pelaku tertanam nilai-nilai dari kedalaman tersembunyi itu. Pelaku kemudian secara sadar melakukan tindakan tersebut dan bertanggung jawab atas tindakan yang ia perbuat. Dalam contoh berkendara, manusia budak akan menggunakan kesadarannya untuk menimbang dan mengukur agar dapat menerabas lampu merah. Ia sebisa mungkin menerabas lampu merah "dengan selamat" tanpa merugikan pengendara lain. Jika ternyata terjadi tabrakan, ia sendiri yang bertanggung jawab atas tindakannya tersebut.

Di tanah tempat eksistensi manusia yang berbahaya, kaum imam, manusia pertama menjadi binatang yang menarik, bahwa hanya di sinilah roh tertinggi manusia mendapatkan kedalamannya dan menjadi jahat (GM I §6). ${ }^{51}$ 
Bornedal mengatakan bahwa dengan kedalaman tersembunyi ini, pembalikan nilai itu menjadi: baik $=$ tuan $=k u a t=$ indah $=$ bahagia $=$ dicintai Tuhan. Dari yang semestinya berarti kuat, tuan, dan indah, yang baik itu kemudian dinilai berdasarkan kedalaman tersembunyi itu, yakni oleh pelaku yang melakukan tindakan itu.

Manusia sejati, yang polos, menurut Bornedal, ${ }^{52}$ senantiasa menghidupi ketaksadarannya. Ia tidak pernah menyadari kesadarannya. Namun, dengan pembalikan nilai itu, manusia yang polos itu akhirnya menyadari dirinya, menyadari kepolosannya. Nilai kepolosan itu lalu dipadankan dengan “tidak melukai”. Yang disebut baik adalah yang secara sadar tidak melukai.

Bornedal $^{53}$ menyatakan bahwa manusia tuan berada di permukaan karena selalu melatih kehendaknya dan sengaja untuk berpaling dari dirinya. Permukaan bagi manusia tuan hanya "menyentuh" inti yang kosong. Kalaupun jatuh ke kedalaman kosong dirinya sendiri, ia segera akan mengabaikannya dengan melupakan sentimen dan emosi dalam dirinya lalu kembali ke permukaan. Bagi manusia tuan, yang disebut permukaan adalah hakikat utama, primer, dan bukan sekunder yang biasa didapat dari meditasi ataupun refleksi. Sebagai hakikat utama, permukaan bersifat instingtif. Manusia tuan tidak perlu menggunakan daya yang berlebihan dalam bertindak. Daya yang berlebihan hanya menunjukkan bahwa insting dalam dirinya sedang bermasalah.

\section{Wanita dan Laki-laki}

Dalam pandangan Bornedal, ${ }^{54}$ konfigurasi manusia tuan dan manusia budak juga dapat dilihat dari dialektika antara kaum wanita dan kaum lelaki. Lelaki tampak begitu kaku dan pemaksa sehingga dikategorikan budak, sedangkan wanita tampak lebih tenang dan instingtif sehingga dikategorikan tuan. Mengutip Pengantar dalam Beyond Good and Evil, Bornedal ${ }^{55}$ menyebut lelaki digambarkan sebagai seorang filsuf dogmatis (metafisika), sementara wanita (kebenaran) digambarkan sebagai idealisasi dari si lelaki.

Andaikan kebenaran adalah seorang wanita — mengapa tidak? Apakah tidak ada alasan untuk mencurigai bahwa semua filsuf, sejauh mereka dogmatis, tidak terlalu memahami wanita? Bahwa keseriusan mereka untuk mendapatkan kebenaran dan sikap kaku mereka sejauh ini tidak layak untuk mendapatkan seorang wanita? Yang pasti adalah wanita tidak akan membiarkan dirinya dipikat—biarkan semua dogmatisme sayu dan layu. Jika mereka memang masih berdiri! (BGE Preface). ${ }^{56}$ 
Dalam penafsiran Bornedal, ${ }^{57}$ para filsuf yang mencari kebenaran dianalogikan sebagai lelaki kaku yang mendekati wanita. Wanita adalah pemilik kebenaran, tetapi hanya dalam kapasitas bahwa wanita memiliki apa yang lelaki tidak miliki, yaitu lingga. Lelaki yang digambarkan telah memberikan lingga kebenaran kepada wanita, dalam prosesnya kehilangan "lingga" miliknya. Namun, wanita sebenarnya tidak memiliki lingga yang oleh lelaki dianggap sebagai kebenaran yang tidak dimiliki oleh lelaki. Wanita hanya bertindak seolah-olah memilikinya.

\begin{abstract}
Wanita, menyadari perasaan lelaki kepadanya, membantu mewujudkan idealisasi lelaki terhadap wanita dengan cara mempercantik diri, berjalan lemah gemulai, menari, berbicara lemah lembut: dengan cara yang sama, wanita akan berperilaku sopan, diam, dan berjarak - menyadari secara instingtif bahwa dengan cara ini, idealisasi lelaki akan tumbuh. (—dengan insting wanita yang pelik, kesopanan merupakan kemunafikan yang disadari: wanita meyakini bahwa kesopanan naif adalah yang paling memikat dan mendorong lelaki untuk mengagung-agungkan wanita. Maka dari itu, wanita itu naifdari kepelikan insting mereka, yang membisikkan mereka tentang perlunya bersikap polos. Suatu kesengajaan untuk tetap-menutup-satu-mata-untuk-orang-lain-Kapan pun ketersembunyian itu memberikan dampak yang semakin kuat karena tidak disadari, ia akan semakin menjadi tidak disadari (Nachlaß 1887, Kritische Studienausgabe/KSA 12, 8[1]). ${ }^{58}$
\end{abstract}

Menurut Bornedal, ${ }^{59}$ aforisme tersebut menggambarkan bahwa wanita tidak memiliki kebenaran. Kebenaran hanyalah atribut tambahan bagi idealisasi dan pengagung-agungan wanita. Wanita mengetahui (tanpa disadari) bahwa lelaki meyakini bahwa wanita memiliki apa yang lelaki tidak miliki. Selain itu, wanita juga mengetahui (tanpa disadari) bahwa jika dalam kesopanan dan kelemahlembutannya, wanita menyamarkan apa yang diyakini lelaki bahwa wanita memiliki apa yang lelaki tidak miliki, maka wanita akan membakukan kepentingan abadinya dan menjadi obyek eksklusif bagi idealisasi lelaki. Dalam dialektika ini, lelaki tampak lebih bodoh ketimbang wanita karena lelaki menginginkan apa yang tidak dimiliki wanita. Wanita hanya memiliki kepura-puraan.

Kekaburan yang diperankan wanita ini, menurut Bornedal, ${ }^{60}$ menjadi utuh karena tetap-menutupsatu-mata-untuk-orang-lain dengan suatu nilai yang disebut kelemahlembutan, selain juga karena wanita mengetahui perlunya kepolosan. Wanita kemudian tidak lagi berpura-pura setelah mengetahui bahwa ketakberpura-puraan mengandaikan kesadaran. Kesadaran yang dimaksud adalah subyek menyadari bahwa wanita tidak berpura-pura karena subyek mengetahui bahwa yang disebut 
kebenaran tidak ada. Wanita akan menutup mata atas kurangnya kebenaran, kurangnya isi dan esensi. Lelaki tidak hanya akan mengagung-agungkan wanita. Wanita pun akan mengagung-agungkan dirinya sendiri.

Dalam penafsiran Bornedal, ${ }^{61}$ wanita meyakini bahwa dia adalah sosok ideal sebagaimana yang dipikirkan lelaki. Namun, wanita sama-sama bersalah karena menipu diri sendiri seperti lelaki. Dalam merepresi kepura-puraannya, wanita secara aktif kehilangan kesadaran akan kepura-puraannya itu. Di sini, wanita juga secara akftif melupakan kepura-puraannya. Oleh karena itu, yang direpresi oleh wanita bukanlah kebenaran, melainkan kurangnya kebenaran. Jika menipu diri yang dilakukan lelaki mengurangi "ada" dirinya, maka menipu diri yang direpresi oleh wanita tidak mengurangi "ada" dirinya. Sebaliknya, wanita menipu diri sendiri karena insting peliknya. Aksi tipu diri yang dilakukan wanita membuat dirinya lebih kuat ketimbang lelaki. Wanita menjadi superior, sedangkan lelaki inferior. Wanita dengan demikian menjadi manusia tuan, sedangkan lelaki menjadi manusia budak.

Menurut Bornedal, ${ }^{62}$ selain superior, wanita juga lebih aktif dibandingkan dengan lelaki. Wanita menggoda lelaki supaya si lelaki menggoda wanita, bahkan wanita membantu idealisasi lelaki dengan cara mempercantik diri, berjalan lemah gemulai, menari-nari, berbicara lemah lembut, dan lain sebagainya. Wanita kemudian akan menjaga jarak dengan lelaki karena wanita mengetahui bahwa semakin wanita menjauh, semakin tinggi keinginan lelaki untuk mengejarnya. Wanita dengan demikian menempatkan dirinya sebagai obyek imajiner: kebenaran.

Di hadapan kebenaran ini, wanita bersikap apa adanya, polos, karena ia memercayainya. Kepolosan ini paradoks karena merupakan ketaksadaran akan ketaksadaran. ${ }^{63}$ Dalam jurang ketaksadaran ini, manusia bukanlah siapa pun dan apa pun, nothing. Nothing ini senantiasa tertambat dalam diri manusia. Manusia tuan akan secara aktif melupakan nothing ini. Dengan kata lain, yang disebut pelupaan adalah melupakan nothing. Pelupaan dengan demikian suatu respons ${ }^{64}$ terhadap ketiadaan esensi dari subyek, suatu inti yang kosong. ${ }^{65}$

Bornedal $^{66}$ mengatakan bahwa pelupaan membantu manusia tuan melupakan nothing, yaitu segala kaos yang berkecamuk dan mengontaminasi dirinya. Kontaminasi ini tidak hanya datang dari dalam, tetapi juga dari luar diri. Pertama-tama, manusia tuan akan melupakan kontaminasi yang muncul dari luar, seperti balas dendam yang dilakukan manusia budak. Manusia tuan kemudian berusaha melupakan kontaminasi yang muncul dari dalam. Dalam jurang ketaksadaran seorang individu, yang ada hanyalah kaos. Segala dorongan, kontradiksi, penilaian, dan inkonsistensi bergerak tunggang 
langgang tak keruan. "Dalam satu individu terdapat kesemrawutan segala macam penilaian, dan kesemrawutan ini juga mengakibatkan kesemrawutan dorongan” (The Will to Power/WP §259).

\section{Kateksis}

Manusia tuan mengerahkan daya ketaksadarannya untuk menjinakkan segala kesemrawutan bak suara centang perenang itu dengan cara menyelaraskan semuanya menjadi suatu harmoni. Dengan kata lain, Bornedal ${ }^{67}$ mengatakan bahwa manusia tuan melakukan hiperkateksis ${ }^{68}$ di dalam dirinya. Manusia tuan hidup dalam daya itu. Daya itu selalu bergerak lurus dari dalam ke luar dan mendorong dirinya di luar. Daya semacam ini bersifat aktif dan merespons inti kosong dalam diri. Dengan daya semacam itu, manusia tuan selalu mencari dirinya dalam segala sesuatu di dalam dirinya.

Adapun manusia budak akan melakukan hiperkateksis apa saja di luar dirinya. Daya manusia budak bergerak memutar dari luar ke dalam, lalu kembali ke luar seperti semula. Artinya, manusia budak akan mengeluarkan segala dayanya untuk mereaksi apa saja yang mengenai dirinya. Manusia budak hidup dalam daya reaktif ini. Ia selalu mencari dirinya dalam segala sesuatu di luar dirinya. Karena hanya mencari di luar dirinya, manusia budak kehilangan dirinya. Kalaupun manusia budak memilikinya, apa saja yang mereka miliki itu pun hanya cerminan dari apa saja yang di luar sana. ${ }^{69}$

Hiperkateksis berasal dari kata kateksis yang berarti 'penimbunan energi psikis yang dipusatkan pada suatu pikiran, ingatan, atau perbuatan'. Hiperkateksis dengan demikian dapat diartikan sebagai penimbunan energi secara berlebihan pada suatu pikiran, ingatan, atau perbuatan. Sebaliknya, dekateksis berarti 'pelepasan energi pada suatu pikiran, ingatan, atau perbuatan' (K. Bertens, Psikoanalisis Sigmund Freud, Jakarta: Gramedia Pustaka Utama, 2016, 260). Helena Ragg-Kirby dalam Sigmund Freud, An Outline of Psychoanalysis, (trans. Helena Ragg-Kirby), London: Penguin Books, 2003, xxiv, mengatakan bahwa kateksis yang berasal dari kata Jerman Besetzung (nomina) dan besetzen (verba) memiliki arti 'penanaman energi pada suatu perbuatan. Penulis mengikuti definisi keduanya, tetapi dalam beberapa kesempatan penulis menggunakan daya sebagai ganti atas energi.

Bornedal $^{70}$ mengatakan bahwa dengan melakukan hiperkateksis di luar dirinya, manusia budak memandang dunia sebagai ancaman dan penuh bahaya. Manusia budak mereaksi apa saja di luar dirinya sehingga dirinya tidak memiliki rasa bahagia. Ia harus menipu diri untuk mendapatkan kebahagiaan, yakni membandingkan dirinya dengan orang lain untuk kemudian melihat apakah 
kebahagiaan yang mereka rasakan sudah sesuai dengan kebahagiaan yang orang lain rasakan. Dengan kata lain, manusia budak melakukan dekateksis diri, yakni melepaskan dirinya untuk dikuasai oleh apa saja di luar dirinya. Karena ketiadaan diri inilah, manusia budak menjadi manusia yang lemah.

Sebaliknya, manusia tuan akan melakukan dekateksis terhadap apa saja di luar dirinya. Manusia tuan tidak menganggap segala sesuatu di luar dirinya sebagai ancaman ataupun bahaya. Selain itu, manusia tuan juga tidak melihat dunia luar dengan penuh rasa curiga, iri, dan ressentiment. Dunia bagi manusia tuan itu menarik dan merupakan cerminan kebahagiaan dari dalam dirinya. ${ }^{71}$

Menurut Bornedal, ${ }^{72}$ berkat hiperkateksis diri, manusia tuan penuh dengan energi. Energi yang melimpah itu bak air mancur yang memerlukan saluran agar air bisa mengalir. Maka, tindakan spontan manusia tuan yang muncul merupakan luapan dari energi itu. Inilah tindakan murni dan inspiratif dari manusia tuan yang tumbuh dari dalam dirinya.

Ketika manusia tuan dihina, ia akan menerimanya. Namun, manusia tuan segera melupakannya tanpa rasa apa pun, bahkan benci sekalipun. Dengan hiperkateksis diri, sentimen negatif, seperti penghinaan, dendam, dan kebencian, tidak akan bertahan lama dalam diri manusia tuan. "Kemampuan untuk menghadapi musuh, musibah, bahkan perlakuan buruk, secara serius tetapi tanpa berlama-lama, itulah ciri orang kuat, penuh energi berlebih untuk membentuk, mencetak, melakukan pemulihan, dan melupakan" (GM I §10). Kemarahan, kebencian, ataupun penghinaan bagi manusia tuan ibarat awan di langit biru yang segera sirna tak berbekas setelah terpapar sinar matahari. ${ }^{73}$

Adapun manusia budak dengan dekateksis diri menciptakan ruang dalam dirinya untuk diisi oleh nilai-nilai atau suara-suara palsu yang berasal bukan dari dirinya. Dekateksis diri ini ibarat sebuah lubang yang memikat untuk segera diisi. Manusia budak tidak akan mempermasalahkan siapa yang meneriakkan suara-suara dan perintah-perintah itu ke telinganya. Ia juga tidak peduli dengan isi perintah-perintah itu karena bagi manusia budak, ia siap mematuhi semuanya itu. ${ }^{74}$

Bornedal $^{75}$ mengatakan bahwa manusia budak membangun di dalam dirinya sebuah "ruang bawah tanah", yakni ruang kosong dan rahasia tempat dia bisa "membudidayakan semua jenis tanaman beracun”. Dengan kata lain, manusia budak menciptakan sosok diri yang palsu, lalu menarik dirinya ke ruang kosong dan rahasia itu untuk mencerna, memperkirakan, dan merefleksikan akibat dari tindakan-tindakan yang belum dilakukan. 
Jika manusia tuan percaya dan terbuka pada diri sendiri [...], manusia ressentiment tidak hanya tidak tulus, naif, jujur, dan terbuka kepada diri sendiri. Jiwa mereka pun sedeng; jiwa mereka suka bersembunyi di tempat gelap, rahasia, dan pintu belakang, atau di mana saja yang bisa dianggap sebagai dunia mereka, rasa aman mereka, rasa nyaman mereka; mereka tahu untuk tenang, tidak lupa, menunggu, meremehkan diri sendiri, merendahkan diri sendiri. Manusia ressentiment pada akhirnya bisa lebih hati-hati ketimbang manusia tuan. Mereka juga memaknai kehati-hatian secara berbeda: yaitu sebagai syarat utama eksistensi manusia (GM I §10). ${ }^{76}$

Bornedal, ${ }^{77}$ dengan mengutip Nietzsche, mengatakan bahwa manusia hari ini adalah binatang sakit. Ia lebih menyukai kedalaman ketimbang permukaan, kesadaran diri ketimbang ketaksadaran, rasa bersalah ketimbang kepolosan, iri ketimbang bangga, tidak bahagia ketimbang bahagia. Ia telah membalik nilai baik menjadi jahat, yang buruk menjadi baik. Namun, semua pembalikan itu menghasilkan manusia-manusia yang lebih pandai, teliti, pintar, dan licik. Itulah mengapa mereka adalah pemenang dalam sejarah peradaban manusia. ${ }^{78}$

\section{Pelupaan dan Ingatan}

Bornedal $^{79}$ mengatakan bahwa konfigurasi manusia tuan dan manusia budak dapat dijelaskan dari dialektika pelupaan dan ingatan. Bagaimana ini dijelaskan? Nietzsche, sebagaimana dikutip Bornedal, ${ }^{80}$ mengatakan bahwa manusia dicirikan oleh yang disebut pelupaan. Dengan pelupaan ini, manusia tidak mampu menepati janjinya. Pelupaan dengan demikian, menurut Bornedal, ${ }^{81}$ bermakna negatif. Namun, bagi Nietzsche, pelupaan bermakna positif karena manusia tuan menggunakan pelupaan untuk merespons ingatan. Ibarat sebuah ruangan yang berisi bermacam-macam ingatan yang tidak berguna, pelupaan akan membuang segala ingatan itu sehingga meninggalkan ruang kosong untuk diisi dengan yang baru.

Jika pelupaan merupakan dimensi mental yang mencirikan kekuatan manusia tuan, ingatan adalah dimensi mental yang mencirikan kelemahan manusia budak. Namun, Bornedal ${ }^{82}$ menafsirkan bahwa Nietzsche kemudian melakukan pembalikan mental. Ingatan menjadi ciri manusia yang kuat, tuan, sedangkan pelupaan menjadi ciri manusia yang lemah, budak. Ingatan kemudian menjadi syarat bagi pelupaan. Manusia yang lemah tidak mampu mengingat. Untuk dapat mengingat, ia perlu mengalami apa yang disebut dengan penderitaan dan penyiksaan. 
Manusia yang bebas, berkehendak kuat, dan berhak membuat janji—di dalam dirinya terdapat kesadaran yang menggetarkan seluruh otot yang akhirnya menjadi daging; itulah kesadaran akan kekuatan dan kebebasan yang membuat dirinya menjadi manusia utuh. Individu yang telah bebas ini, yang berhak membuat janji, yang berkuasa atas kehendak bebasnya, dan yang berdaulat [...] melihat orang lain dengan rasa hormat dan benci, sebagaimana ia menghormati kawannya yang kuat, yang enggan, lambat, dan ragu-ragu memercayai-kepercayaan adalah ciri mereka sehingga ucapannya dapat dipercaya dan mereka cukup kuat memegang ucapannya dalam menghadapi segala peristiwa, $[\ldots]$ ia dapat menyepak para pembual yang tidak punya hak untuk membuat janji, dan mencambuk pembohong yang melanggar kata-katanya sesaat setelah ia mengucapkan kata-kata itu (GM II §2). ${ }^{83}$

Dengan demikian, menurut Bornedal, ${ }^{84}$ Nietzsche melakukan apa yang disebut dengan kiasma, yaitu mengubah dua posisi lalu menempatkannya secara menyilang seperti huruf X. Dalam silangan pertama ( ), di posisi pertama, pelupaan merupakan ciri manusia tuan, sedangkan posisi kedua merupakan ciri medioker (pembual) manusia budak. Dalam silangan kedua (/), di posisi pertama, ingatan merupakan ciri manusia budak, sedangkan posisi kedua merupakan ciri integritas (dapat dipercaya) dari manusia tuan. Manusia tuan berhak dan mampu membuat atau menepati janji, sedangkan kaum budak tidak memiliki hak itu sehingga tidak mampu membuat atau menepati janji.

Meskipun pelupaan merupakan ciri manusia tuan, kata Bornedal, ${ }^{85}$ tidak berarti manusia tuan menghapus apa saja yang ada dalam ingatannya. Manusia tuan masih menyisakan sedikit tabula rasa kesadaran sehingga jiwanya tidak sepenuhnya kosong. Ia tentu saja akan mengingat kehendak kuasa dalam dirinya. Manusia tuan bisa saja lupa akan yang lain, tetapi ia tidak melupakan kehendak kuasanya. Ketika berbicara tentang ingatan manusia tuan, menurut Bornedal, Nietzsche tengah berbicara tentang ingatan akan kehendak, yang di dalamnya melibatkan hasrat akan sesuatu yang sebelumnya telah dikehendaki.

Binatang pelupa, yang baginya pelupaan merupakan perwujudan kuasa, semacam kesehatan yang prima, sekarang melahirkan fakultas berlawanan, yang disebut ingatan, yang dengannya pelupaan dibatalkan dalam situasi tertentu—yaitu dalam situasi ketika janji dibuat. Proses ini melibatkan tidak melulu kepasifan ketidakmampuanmenghilangkan segala kesan dalam jiwanya, [...] tetapi suatu kehendak aktif untuk tidak menyingkirkan yang lain, suatu kehendak untuk melanjutkan sesuatu yang sebelumnya sudah dikehendaki, suatu ingatan akan kehendak (GM II §1). ${ }^{86}$ 
Dalam pandangan Bornedal, ${ }^{87}$ pelupaan disebut aktif jika ia menciptakan ruang untuk sesuatu. Artinya, pelupaan menyediakan tempat bagi yang lain untuk diingat dengan cara membersihkan jiwa dan membuang apa saja yang tidak berguna. Meskipun sudah dibersihkan, jiwa masih meninggalkan sesuatu. Ketika suatu janji diucapkan, sesuatu yang tertinggal itu disebut kata. Manusia tuan akan selalu ingat kata-kata dalam janji itu. Dalam jurang terdalam dirinya, yang pada dasarnya nothing alias hanya centang perenang opini, nilai-nilai, dorongan, dan lain sebagainya, manusia tuan menanamkan dalam dirinya suatu tanggung jawab, kemampuan bertanggung jawab, dan sifat dapat dipertanggungjawabkan dengan cara memaksa dirinya mengingat kata, ${ }^{88}$ tanda, sebagai keutamaan dirinya. Adapun manusia budak hanya mengingat emosi-emosi masa lalu yang berhubungan dengan penderitaan. Di hadapan aturan atau hukum, manusia tuan akan menanamkan aturan itu dalam bentuk kata, penanda, sedangkan manusia budak mengingatnya hanya sebagai jejak-jejak penderitaan atau hukuman yang diakibatkan oleh ketidaktaatan atau perbuatan melawan hukum itu. Manusia budak menjadi manusia tercela karena ia tak berhukum. Tak berhukum di sini, menurut Bornedal, dalam arti manusia budak tidak menanamkan hukum dalam dirinya sendiri. Karena tak berhukum, manusia budak tidak berhak untuk membuat janji.

Dalam hidup bermasyarakat, manusia tuan juga akan menanamkan hukum dalam masyarakat tersebut. Ia pertama-tama akan menanamkan hukum itu dalam dirinya, lalu menanamkannya dalam masyarakat. Hukum dengan demikian bukanlah reaksi dari manusia budak ataupun reaksi atas rasa iri, benci, dan ressentiment terhadap yang kuat. ${ }^{89}$ "Dari sudut pandang sejarah, hukum merepresentasikan [...] perjuangan melawan perasaan reaktif. Di mana pun keadilan dijalankan dan ditegakkan, seseorang akan mencari kuasa yang lebih kuat untuk membasmi ressentiment di antara kaum lemah. [...] Tindakan paling tegas yang di dalamnya kuasa tertinggi muncul dan berhasil melawan kebencian dan dendam [...] adalah penegakan hukum” (GM II §11). ${ }^{90}$

Salah satu tafsir dari aforisme tersebut, dalam pengamatan Bornedal, ${ }^{91}$ menyatakan bahwa manusia tuan cenderung anarkistis (memberontak), sedangkan manusia budak konformistis (patuh). Namun, dalam penafsiran Bornedal, manusia tuan membuat aturan atau hukum untuk memberangus anarkisme manusia budak dengan menegakkan keadilan. Salah satu fakultas mental yang penting dalam konfigurasi asertif adalah kemampuan untuk bertindak secara adil. Berbuat adil merupakan respons manusia tuan terhadap kaos. Adapun manusia budak tidak dapat mereaksi kaos dalam dirinya karena dia sendiri adalah kaos. Ucapan dan opini manusia budak hanyalah celoteh berisi kebencian dan dendam. Karena manusia budak tidak dapat melupakan jejak-jejak ingatannya, ia membenamkan 
diri ke dalam hal-hal yang bersifat materi. Manusia budak tidak mampu keluar dari dirinya sehingga tidak mampu melihat dengan tatapan tajam dan terukur.

Muncul dari jurang yang kosong, menurut Bornedal, ${ }^{92}$ keadilan kemudian menjadi standar yang berlaku universal untuk mengukur tindakan manusia. Manusia tuan menerapkan standar universal itu sebanyak mungkin dalam dirinya sendiri.

\section{Rasa Bersalah}

Bornedal, ${ }^{93}$ dengan mengutip Nietzsche, mengatakan bahwa manusia disituasikan dalam pelupaan. Ketika pada suatu titik, manusia lupa dan dihinggapi rasa bersalah, ia pun menerima hukuman. Pada zaman prasejarah, rasa bersalah ini tidak memiliki daya rusak seperti yang dipahami kemudian, dan hukuman hanyalah perwujudan dari kekejaman atau kekerasan. Mereka harus belajar mengingat dan bertanggung jawab.

Manusia tidak mampu memegang janji. Ketika kemudian ia mampu memegang janjinya, hal itu terjadi bukan karena pada mulanya manusia menyadari ada nilai, misalnya nilai kewajiban sebagai hukum universal, yang harus mereka taati untuk memegang janji itu. Manusia mampu memegang janjinya karena ditempa, digembleng, bahkan dihukum agar ingat akan janjinya. Hukuman tersebut bahkan bisa dalam wujud tindakan fisik yang kejam, yaitu penyiksaan. ${ }^{94}$

Jika apa saja yang ada dalam ingatan harus dibakar, hanya ingatan tentang sesuatu yang tidak pernah berhenti menyakitilah yang tidak akan terbakar. [...] Manusia tidak dapat lepas dari darah, penyiksaan, dan pengorbanan ketika ingin mengingat sesuatu (GM II $\S 3) .{ }^{95}$

Dengan perlakuan fisik yang kejam, manusia dilatih untuk mengingat janjinya dan belajar tanggung jawab. Pada zaman ini, hukuman fisik itu tidak menimbulkan luka mental yang permanen karena mereka belum memiliki kesadaran tentang apa itu rasa bersalah. Baru setelah memasuki zaman sejarah, ketika nilai-nilai diciptakan dan kesadaran akan rasa bersalah muncul, hukuman atas rasa bersalah itu menjadi begitu menyakitkan. Di hadapan nilai agama, misalnya, manusia merasa bersalah dan berdosa di hadapan Tuhan. ${ }^{96}$ 
Rasa bersalah, menurut Nietzsche, ${ }^{97}$ berasal dari kata dalam bahasa Jerman, Schuld, yang berarti 'rasa bersalah' dan 'utang'. Schuld diturunkan dari kata Schulding yang berarti 'merasa berutang' atau 'merasa bersalah'. Oleh karena itu, merasa bersalah juga berarti merasa berutang. Dengan kata lain, orang yang berutang (debitor) akan merasa bersalah jika ia tidak dapat membayar utang kepada pengutang (kreditor). Jika debitor tidak dapat membayar utang, kreditor berhak memberikan hukuman kepada debitor. Debitor pun merelakan dirinya dihukum karena ia merasa bersalah karena gagal membayar utang.

Menurut Bornedal, ${ }^{98}$ kata Schuld ini kemudian mengalami transformasi moral psikologis, dari Schuld sebagai utang (debt) ke Schuld sebagai rasa bersalah (guilt) ataupun dari hubungan rasa bersalah dan utang (guilt-debt) menjadi hubungan rasa bersalah dan agresi diri (guilt-self-aggression). Transformasi ini menghasilkan individu yang lemah dan terpenjara. Ketika kondisi masyarakat semakin berkembang dan menekan, manusia menjadi terpenjara dan lemah karena ia tidak mampu menghadapinya. Ia kemudian menginternalisasikan rasa bersalah dan agresi diri sebagai akibat dari ketidakmampuannya itu.

Bornedal $^{99}$ mengatakan bahwa rasa bersalah dari hubungan debitor dan kreditor yang eksternal itu ditarik ke internal (mental) diri yang bersalah, yaitu yang berutang itu sendiri. Sebagai debitor, ia harus membayar utang kepada kreditor yang adalah dirinya sendiri. Jika sebagai debitor tidak mampu membayar utangnya, sang kreditor yang adalah dia sendiri berhak menghukum atau menyerang debitor yang adalah dia sendiri juga. Di sinilah transformasi moral psikologis itu terjadi. Setelah diinternalisasikan, rasa bersalah berubah menjadi agresi diri, dan hukumannya bukan lagi dalam wujud fisik, melainkan spiritual.

Ketika hubungan antara kreditor dan debitor yang eksternal itu ditransformasikan secara moral dan internal, menurut Bornedal, ${ }^{100}$ Nietzsche tengah menunjukkan konfilik internal psikologis, yaitu antara kreditor yang agresif menghukum/menyerang debitor dan debitor yang menerima hukuman itu. Ketika hubungan itu diinternalisasikan, debitor memiliki utang kepada kreditor yang tidak akan pernah dapat dibayar. Debitor akhirnya merasa bersalah, dan kreditor berhak menghukum/menyerang debitor. Bagi kreditor, hukuman/serangan/agresi ini bersifat aktif dan primer yang disebut dengan sadisme. Namun, bagi debitor, hukuman/serangan/agresi yang aktif dan primer itu berbalik menjadi pasif dan sekunder yang disebut dengan masokhisme. 
Bornedal $^{101}$ mengatakan bahwa ketimbang menikmati melukai orang lain atau melihat orang lain terluka (protosadisme), manusia lebih menikmati melukai diri sendiri ataupun melihat diri sendiri terluka (protomasokhisme). Dua proses inilah yang, menurut Bornedal, membedakan antara manusia tuan dan manusia budak. Ketika indra diarahkan ke luar, ia membuat dirinya dipenuhi oleh apa pun di luar. Sebagai subyek, dia menjadi manusia utuh (individuum) dan tidak terbagi (dividuum). Inilah yang disebut sebagai manusia tuan. Sebaliknya, ketika indra diarahkan ke dalam, ia membawa masuk apa pun yang di luar ke dalam dirinya. Lalu ia akan menilai apa pun yang masuk itu. Ia pun menjadi terbelah. Sebagai subyek, dia menjadi manusia yang terbelah dan tidak utuh. Inilah yang disebut dengan manusia budak.

Semua insting yang tidak dapat dilepaskan ke luar tetapi justru berbalik ke dalam: inilah yang aku sebut dengan internalisasi. Inilah yang kemudian manusia menyebutnya sebagai "jiwa". Dunia dalam dirinya, yang tipis seolah-olah seperti dua selaput yang direntangkan, memperluas dan memperpanjang dirinya, memperolah kedalaman, keluasan, dan ketinggian, sama seperti ketika dia melepaskan apa saja yang ada dalam dirinya ke luar dirinya. [...] Insting permusuhan, kekerasan, kebahagiaan ketika menghukum, menyerang, membalas, merusak—semuanya berbalik menyerang dirinya sendiri: itulah asal usul kesadaran yang buruk (GM II $§ 16) .{ }^{102}$

Mengutip aforisme tersebut, Bornedal ${ }^{103}$ mengatakan bahwa agresi primer yang berbalik dan mengarah ke diri sendiri dapat terjadi karena proses peradaban. Ketika manusia hidup dalam suatu lingkungan, komunitas, atau masyarakat, insting yang ada dalam dirinya menjadi terpenjara karena lingkungan tidak membolehkan agresi diarahkan ke luar dirinya. Alih-alih menggunakan instingnya untuk menyerang musuh, ia justru menggunakan instingnya untuk menyerang diri sendiri.

Isi kesadaran. - Isi kesadaran kita adalah apa saja yang selama masa kanak-kanak mengatur kita tanpa sebab dari orang yang kita hormati atau takuti. Inilah kesadaran memerintah ("Aku harus begini, tidak begitu") yang tidak bertanya: mengapa aku harus? - Dalam setiap tindakan yang dilakukan dengan "karena" dan bukan "mengapa", manusia bertindak tanpa kesadaran. - Keyakinan terhadap yang berkuasa adalah sumber dari kesadaran: oleh karena itu, kesadaran bukanlah suara Tuhan dalam hati manusia, melainkan suara manusia dalam manusia (HAH II/2, 52). ${ }^{104}$ 
Yang disebut kesadaran dengan demikian berisi suara manusia dalam diri manusia, dan bukan suara Tuhan. Suara manusia itu bisa berupa aturan, larangan, perintah, kebiasaan, norma, dan hukum yang sudah diterima manusia sejak dia lahir. ${ }^{105}$

\section{Penutup}

Dalam Beyond Good and Evil §227, Nietzsche bertanya, "Bukankah dewa-dewa sejauh ini ... sudah menjadi iblis yang suci dan telah dibaptis lagi?" Nietzsche ingin menunjukkan bahwa dalam tindakan dan nilai yang disebut imoral dan jahat adalah hal yang diperlukan agar suatu tindakan dan nilai yang disebut moral dan baik itu mungkin. ${ }^{106}$ Apakah dengan demikian tindakan dan nilai seperti itu merupakan dua hal yang berbeda? Bahwa pada dasarnya keduanya bertentangan satu sama lain? Apakah setiap bagiannya memiliki ciri pada dirinya sendiri, terlepas untuk apa dan siapa yang menggunakannya? Apakah beberapa nilai dan tindakan perlu dihargai, sedangkan yang lain ditentang? Jawaban Nietzsche adalah bahwa "di antara tindakan baik dan jahat tidak ada perbedaan spesies, kecuali pada derajatnya. Tindakan baik adalah tindakan jahat yang disublimasi; tindakan jahat adalah tindakan baik yang divulgarisasi dan dibius” (HAH I §107). ${ }^{107}$

Dalam Thus Spoke Zarathustra I §8, Nietzsche menggambarkan kesatuan antara baik dan jahat dalam metafora pohon: "Manusia seperti halnya pepohonan. Semakin mereka menginginkan ketinggian dan cahaya, semakin kuat akar mereka menghunjam ke bumi, ke bawah, ke dalam kegelapan, jauh ke dalam-kejahatan.” Dari metafora itu, Nietzsche menyatakan bahwa nilai baik dan jahat sama-sama menjadi bagian dalam kehidupan, dan nilai jahat tidak dapat dihilangkan. Selain itu, Nietzsche juga menyatakan bahwa nilai jahat tidak hanya tidak dapat dihilangkan, tetapi juga diperlukan dalam mendapatkan nilai baik. Bahkan, Nietzsche mengatakan bahwa hasrat akan nilai jahat adalah hasrat yang memberikan hasil terbaik, terbesar, dan paling dikagumi. ${ }^{108}$

Dalam Twilight of the Idols VII §1, Nietzsche mengatakan, "Permintaanku kepada para filsuf sudah jelas bahwa mereka mesti berpijak melampaui baik dan jahat dan meninggalkan ilusi penilaian moral di bawah kaki mereka. Permintaan ini muncul dari pemahaman yang aku rumuskan: bahwa tidak ada fakta-fakta moral." Pernyataan Nietzsche tersebut mengimplikasikan bahwa jika tidak ada fakta moral, maka juga tidak ada nilai baik dan buruk. ${ }^{109}$ Nietzsche kemudian mengatakan, "Tujuanku: menunjukkan bahwa homogenitas absolut semua peristiwa dan penerapan nilai moral itu perspektif; menunjukkan bahwa apa saja yang disebut moral pada dasarnya identik dengan apa saja yang disebut 
imoral” (WP §272). Nietzsche hendak mengatakan bahwa perbedaan antara baik dan jahat menjadi sumir karena baik bagi yang satu bisa jadi jahat bagi yang lain, pun demikian sebaliknya. ${ }^{110}$

Kesumiran itu tampak jelas ketika Nietzsche mengatakan bahwa kaum tuan di satu sisi adalah kaum barbar dan kejam sehingga dianggap sebagai musuh yang berbahaya. Di sisi lain, mereka juga "penuh pertimbangan, mampu menguasai diri, tenang, loyal, percaya diri, dan bersahabat” (GM I §11). Di antara sesama kaum tuan, tumbuh rasa saling menghormati. Kalaupun terjadi perselisihan yang menimbulkan korban atau luka, hal itu bukan masalah karena level mereka sama. Namun, apabila nilai yang dianut kaum tuan ini diberlakukan universal sebagai nilai hidup bersama, Nietzsche mengatakan bahwa nilai itu hanya akan mengakibatkan "perpecahan dan akhirnya membusuk" (BGE $\S 259) .{ }^{111}$

Nietzsche juga mengatakan bahwa dalam moral tuan, nilai baik dan jahat pada dasarnya saling terkait dan tidak bertentangan. "Rasa cinta dan benci, rasa syukur dan dendam, ketenangan dan kemarahan, afirmasi dan reaksi menjadi satu. Seseorang tahu apa itu baik dan apa itu jahat; seseorang menjadi jahat karena dia tidak tahu bagaimana menjadi baik" (WP $§ 351) .{ }^{112}$

Meskipun demikian, Nietzsche tidak bermaksud mendorong seseorang untuk bertindak jahat. Nietzsche hanya ingin menunjukkan bahwa kehendak kaum tuan dapat menghasilkan suatu nilai jahat dalam situasi tertentu. Nietzsche mengatakan, 'Hampir semua yang kita sebut 'kebudayaan tinggi' mendasarkan spiritualitas mereka pada kekejaman... 'Binatang buas' itu belum sepenuhnya 'mati'; dia hidup dan terus tumbuh, ia senantiasa menjadi-ilahi” (BGE §229). Kekejaman kaum tuan itu muncul dari kehendak yang tidak perlu dihilangkan, tetapi diterima untuk kemudian disublimasi. Jika tidak mampu melakukan sublimasi, kaum tuan juga bisa menjadi kaum budak. ${ }^{113}$

Menurut Bornedal, ${ }^{114}$ Nietzsche melakukan penyederhanaan dalam usahanya mencari pendasaran tentang yang disebut baik dan jahat. Dari penyelidikan yang ia lakukan, Bornedal menengarai bahwa upaya Nietzsche menggunakan aspek sejarah, sosiologi, antropologi, filologi, dan psikologi untuk kemudian merelasikan semuanya menjadi apa yang disebut baik dan jahat hanyalah penyederhanaan proses mental, dorongan, dan penilaian. Padahal, proses mental, dorongan, dan penilaian tersebut, menurut Bornedal, terlalu kompleks untuk dipahami.

Meskipun demikian, Bornedal ${ }^{115}$ mengatakan bahwa perbedaan antara yang baik dan jahat tidak pernah kokoh dan selalu merupakan suatu oposisi yang tidak stabil. Ketidakstabilan itu tidak lebih 
dari sebuah perbedaan tingkatan dari yang sama (different degrees of the same). Artinya, yang disebut baik dan jahat bisa bertukar makna dan nilai satu dengan yang lain. Selain itu, antara yang baik dan jahat juga dapat saling membalik makna dan nilai di antara keduanya. ${ }^{116}$

Dalam pandangan Bornedal, ${ }^{117}$ definisi baik dan jahat saling melengkapi satu dengan yang lain. Bornedal mengatakan bahwa secara antropologis yang disebut jahat tidak dapat dihilangkan. Namun, dari aspek pragmatik-linguistik, Bornedal menyatakan bahwa penghilangan makna dapat terjadi jika sistem nilai dihilangkan. Artinya, definisi baik tidak akan terpenuhi jika tidak ada pengetahuan sebelumnya atas apa yang disebut dengan jahat. Begitu juga definisi jahat tidak akan terpenuhi jika tidak ada pengetahuan sebelumnya tentang apa yang disebut baik. Sebagi suatu nilai, baik dan jahat “duduk berdampingan".

Selain itu, Bornedal ${ }^{118}$ juga menyatakan bahwa baik dan jahat merupakan oposisi relatif yang terkait dengan proses pembentukan (asal usul) makna baik dan jahat itu sendiri. Baik dan jahat saling terkait dan tidak dapat dipisahkan. Yang disebut baik bisa berasal dari pelabelan ulang secara eufemistis dari sesuatu yang disebut jahat. Artinya, di dalam satu klaster semantik terdapat sesuatu yang disebut baik, tetapi klaster itu kemudian terbelah menjadi dua. Di klaster semantik kedua ini terdapat makna baru, yaitu jahat, yang berlawanan dengan makna di klaster pertama. Alhasil, yang disebut baik dan jahat bisa jadi memiliki asal usul yang sama. Yang disebut "kehendak baik" bisa jadi merupakan hasil sublimasi dari apa yang disebut "kekejaman".

Dalam kehendak baik ada hasrat perbaikan untuk dimiliki. [...] Segera setelah perbaikan muncul, tingkatan sebelumnya tidak lagi menjadi suatu tingkatan, tetapi lebih sebagai sebuah oposisi. Lebih mudah memikirkan oposisi ketimbang gradasi. [...] ketika dorongan yang kompleks menciptakan nama, dan dianggap sebagai suatu kesatuan, nama itu mulai bertindak sewenang-wenang terhadap semua pemikir, yang sekarang sedang mencari definisi $\left\{(\right.$ Nachlaß 1881, KSA 9, 11 (115) $\} .{ }^{119}$

Ketika sebuah dorongan menjadi intelektual, ia kemudian memunculkan sebuah nama baru, stimulus baru, dan nilai baru. Dorongan ini akan sering diperlawankan dengan dorongan sebelumnya sebagai kontradiksi-Banyak dorongan, misalnya dorongan seksual, merupakan hasil dari perbaikan intelektual \{(Nachlaß 1881, KSA 9, 11 (124) . $^{120}$ 
Bornedal $^{121}$ memberikan contoh bahwa pada Abad Pertengahan, seseorang yang berbuat jahat akan dihukum secara fisik, misalnya disiksa, dirajam, dipenggal, dibakar, diseret, dan digantung. Adapun pada zaman modern, seseorang yang berbuat jahat akan "dihilangkan" alias dipenjara selama beberapa lama, entah satu hari, satu minggu, satu bulan, satu tahun, sepuluh tahun, bahkan ada yang sampai menemui ajalnya alias dihukum seumur hidup. Rezim zaman modern seolah-olah menunjukkan bahwa mereka berbeda atau berlawanan/beroposisi dengan rezim lama. Namun, menurut Bornedal, apa yang dilakukan oleh rezim zaman modern sama dengan rezim lama. Bedanya hanya mengubah bentuk "kekejaman" (hukuman), dari yang awalnya menghukum secara fisik menjadi menghukum secara psikis.

Tegangan antara yang baik dan jahat ini, menurut Bornedal, ${ }^{122}$ juga dapat dilihat dari para penganut agama. Bagi orang beragama, perbedaan antara baik dan jahat itu ibarat jurang yang paling dalam. Dengan kata lain, nilai-nilai yang terkandung dalam kebaikan berbeda dengan nilai-nilai dalam kejahatan. Singkatnya, mereka sama sekali berbeda. Tidak dapat dimungkiri bahwa orang beragama mengejar yang baik. Sebisa mungkin dia akan menolak yang jahat. Namun, dalam upaya menjadi yang baik itu, ia melihat yang disebut jahat terserak di mana-mana, dan itu di dalam diri manusia. Secara paradoks, Bornedal mengatakan, orang beragama dan baik itu dikuasai oleh kebencian. Ia membenci dosa dan membenci orang yang berdosa. Bahkan, ia membenci yang jahat dalam dirinya sendiri, kemudian ingin lepas dari dunia yang jahat ini dengan melakukan balas dendam.

\section{Daftar Pustaka}

Allison, David B. Reading the New Nietzsche, The Birth of Tragedy, The Gay Science, Thus Spoke Zarathustra, and On the Genealogy of Morals. Maryland: Rawman \& Littlefield Publisher, Inc. 2001.

Anderson, Mark. Plato and Nietzsche, Their Philosophical Art. London: Bloomsbury. 2014.

Bertens, K. Psikoanalisis Sigmund Freud. Jakarta: Gramedia Pustaka Utama. 2016.

Bornedal, Peter. The Surface and the Abyss: Nietzsche as Philosopher of Mind and Knowledge. Berlin: De Gruyter. 2010.

Conway, Daniel. Nietzsche's On the Genealogy of Morals, A Reader's Guide. Cornwall: Continuum. 2008. 
Freud, Sigmund. An Outline of Psychoanalysis. (trans. Helena Ragg-Kirby). London: Penguin Books. 2003

HarperCollins Publisher. Collins Cobuild English Dictionary for Advanced Learners. Glasgow: HarperCollins Publisher. 2001.

Nehamas, Alexander. Nietzsche Life as Literature. Massachusetts: Harvard University Press. 1985.

Nietzsche, Friedrich. Beyond Good and Evil, Prelude to a Philosophy of the Future. (trans.) Judith Norman. Cambridge: Cambridge University Press. 2002.

. Beyond Good and Evil, Prelude to a Philosophy of the Future. (trans.) R. J.

Hollingdale. London: Penguin Classics. 2014.

. Human, All Too Human I, The Complete Works of Friedrich Nietzsche 3,

(trans.). Gary Handwerk. California: Standford University Press. 1995.

. Human, All Too Human II, The Complete Works of Friedrich Nietzsche 4,

Unpublished Fragments from the Period of Human, All Too Human II (Spring 1878-Fall

1879). (trans.). Gary Handwerk. California: Standford University Press. 2013. . Human, All too Human, A Book for Free Spirits. (trans.) R. J. Hollingdale.

Cambridge: Cambridge University Press. 1996.

. On the Genealogy of Morals. (trans.) Carol Diethe. Cambridge: Cambridge

University Press. 2006.

. On the Genealogy of Morality. (trans. and ed.) Maudemarie Clark and Alan J.

Swensen. Indiana: Hackett Publishing Company, Inc. 1998.

. On the Genealogy of Morals. (trans.) Walter Kaufmann and R. J. Hollingdale.

New York: Vintage Books. 1989.

. The Will to Power (trans.) Walter Kaufmann and R. J. Hollingdale. New York:

Vintage Books. 1968.

. Thus Spoke Zarathustra, A Book for All and None. (trans.) Adrian Del Caro.

Cambridge: Cambridge University Press. 2006.

. The Will to Power, Selection from Notebooks 1880s. (trans.) R. Kevin Hill and

Michael A. Scarpitti). London: Penguin Books. 2017.

Owen, David. Nietzsche's Genealogy of Morality. Stocksfield: Acumen. 2007.

Richardson, John. Nietzsche’s System. New York: Oxford University Press. 1996.

Sadler, Ted. Nietzsche: Truth and Redemption, Critique of the Postmodernism Nietzsche. London:

The Athlone Press. 1995.

Strong, Tracy B. Friedrich Nietzsche and the Politics of Transfiguration, Expanded Edition. London: University of California Press. 1988. 
Badan Pengembangan dan Pembinaan Bahasa. KBBI Daring. https://kbbi.kemdikbud.go.id/reaktif. Jakarta: Kementerian Pendidikan dan Kebudayaan Republik Indonesia. 2016. Diakses pada tanggal 15 Mei 2021.

KBBI Daring. https://kbbi.kemdikbud.go.id/responsif. Jakarta: Kementerian

Pendidikan dan Kebudayaan Republik Indonesia. 2016. Diakses pada tanggal 15 Mei 2021. Tesaurus Tematis Bahasa Indonesia. http://tesaurus.kemdikbud.go.id/tematis/

lema/agresif. Jakarta: Kementerian Pendidikan dan Kebudayaan Republik Indonesia. 2021.

Diakses pada tanggal 15 Mei 2021.

Oxford University Press. Lexico.com. lexico.com/definition/reactive. Oxford: Oxford University Press. 2021. Diakses pada tanggal 15 Mei 2021. - Lexico.com. lexico.com/definition/responsive. Oxford: Oxford University

Press. 2021. Diakses pada tanggal 15 Mei 2021. Lexico.com. lexico.com/definition/servile. Oxford: Oxford University Press.

2021. Diakses pada tanggal 15 Mei 2021.

1 Bornedal menggunakan servile configuration untuk menyebut tipe moral budak. Collins Cobuild English Dictionary for Advanced Learners, Glasgow: HarperCollins Publishers, 2001, 1416, dan lexico.com/definition/servile mendefinisikan servile (adjektiva) — jika diterjemahkan ke dalam bahasa Indonesia — sebagai kurang lebih 'berkenaan dengan budak'. Arti ini, dari aspek ekonomi kata, menurut penulis, tidak efisien. Untuk itu, penulis menerjemahkan servile menjadi agresif yang berarti 'bersifat atau bernafsu menyerang' (https://kbbi.kemdikbud.go.id/entri/agresif) sebagai kebalikan dari asertif yang berarti 'tegas' (http://tesaurus.kemdikbud.go.id/tematis/lema/agresif). Dua kata tersebut, menurut penulis, cukup mewakili ciri masing-masing tipe. Dalam beberapa kesempatan, penulis tetap menggunakan manusia tuan dan manusia budak sebagai substitusi konfigurasi asertif dan konfigurasi agresif karena Nietzsche sendiri menyebutnya demikian: moral tuan dan dan moral budak (Lih. Beyond Good and Evil/BGE §260). Ketika Nietzsche mengatakan bahwa dalam satu subyek terdapat moral tuan dan moral budak, hal tersebut, menurut Bornedal, hanya menggambarkan aspek eksternal dan tidak menunjukkan aspek internal subyek (in-iself). Alhasil, dimensi psikologis, seperti dorongan dan energi, tidak muncul. Itulah mengapa Bornedal lebih memilih menggunakan istilah konfigurasi (Peter Bornedal, The Surface and the Abyss: Nietzsche as Philosopher of Mind and Knowledge, Berlin: De Gruyter, 2010, 360).

2 Peter Bornedal, The Surface and the Abyss: Nietzsche as Philosopher of Mind and Knowledge, 358.

3 Bornedal tidak menyebutkan formasi apa yang dimaksud untuk konfigurasi moral tuan. Menurut penulis, moral tuan dan moral budak akan selalu jalan beriringan karena mereka satu kesatuan dan tidak dapat dipisahkan. Mereka hanya berbagi peran berlawanan. Nietzsche dalam Beyond Good and Evil §260 menyebutkan secara eksplisit bahwa dalam satu jiwa terdapat moral tuan dan moral budak. Bornedal sendiri juga mengutip Beyond Good and Evil §260 untuk menunjukkan kesatuan ini (Peter Bornedal, The Surface and the Abyss: Nietzsche as Philosopher of Mind and Knowledge, 360).

4 Peter Bornedal, The Surface and the Abyss: Nietzsche as Philosopher of Mind and Knowledge, 361-362.

5 Peter Bornedal, The Surface and the Abyss: Nietzsche as Philosopher of Mind and Knowledge, 363-364.

6 Friedrich Nietzsche, On the Genealogy of Morality, (trans. and ed.) Maudemarie Clark and Alan J. Swensen, Indiana: Hackett Publishing Company, Inc. 1998, 12.

7 Mark Anderson dalam Plato and Nietzsche, Their Philosophical Art, London: Bloomsbury, 2014, 143. Analisis A. Setyo Wibowo dalam kuliah Gaya Filsafat Nietzsche dan Genealogi Moral di Program Pascasarjana STF Driyarkara, 12 September 2019, membantu penulis dalam membaca Anderson.

8 David B. Allison, Reading the New Nietzsche, The Birth of Tragedy, The Gay Science, Thus Spoke Zarathustra, and On the Genealogy of Morals, Maryland: Rawman \& Littlefield Publisher, Inc, 2001, 202. Bdk. John Richardson, Nietzsche’s System, New York: Oxford University Press, 1996, 53-57. 
9 Mark Anderson, Plato and Nietzsche, Their Philosophical Art, 144. Bdk. David Owen, Nietzsche's Genealogy of Morality, Stocksfield: Acumen, 2007, 77.

10 Lih. On the Genealogy of Morals I $\$ 11$.

11 Mark Anderson dalam Plato and Nietzsche, Their Philosophical Art, 144, mengatakan, "It is not that they hate the stranger; they are indifferent to him, simply fail to take stock of him in their accounting of those features of the world that matter. They act as they do also because they are naturally powerful and strong, and power and strength exist in and through their expression and discharge. In other words, these men are not 'free' to restrain or check their outflow of force, for they themselves just are an outflowing of force."

12 Peter Bornedal, The Surface and the Abyss: Nietzsche as Philosopher of Mind and Knowledge, 363-364.

13 Peter Bornedal, The Surface and the Abyss: Nietzsche as Philosopher of Mind and Knowledge, 364.

14 Lih. On the Genealogy of Morals I §5.

15 David B. Allison, Reading the New Nietzsche, The Birth of Tragedy, The Gay Science, Thus Spoke Zarathustra, and On the Genealogy of Morals, 202.

16 Mark Anderson dalam Plato and Nietzsche, Their Philosophical Art, 144, mengatakan, "The kaloi kagathoi are eminently healthy, vigorous, and robust, and they recognize the fact, even celebrate themselves for it; thus they avoid, and in some cases even ritually avoid, situations in which, and contact with people by whom, their wellbeing might be undermined and they themselves corrupted. Overflowing with vitality as they are, these master types thrive on adventure, war, athletic competition, and the hunt-any activity in which they might give vent to their power and their delight in power."

17 Peter Bornedal, The Surface and the Abyss: Nietzsche as Philosopher of Mind and Knowledge, 364.

18 David B. Allison dalam Reading the New Nietzsche, The Birth of Tragedy, The Gay Science, Thus Spoke Zarathustra, and On the Genealogy of Morals, 202, mengatakan, "By opposition, and still from the perspective of the ruling class, the subordinate class, far greater in number and far weaker in virtue, were called the hoi polloi, 'the undistinguished multitude, 'the many, the demos, the wonder-loving herd." (Lih. GM I §5).

19 Friedrich Nietzsche, On the Genealogy of Morals (trans. Walter Kaufmann and R. J. Hollingdale), New York: Vintage Books, 1989, 28.

20 David B. Allison, Reading the New Nietzsche, The Birth of Tragedy, The Gay Science, Thus Spoke Zarathustra, and On the Genealogy of Morals, 203.

21 Mark Anderson dalam Plato and Nietzsche, Their Philosophical Art, 143.

22 Mark Anderson dalam Plato and Nietzsche, Their Philosophical Art, 143, mengatakan, "Good, the more central of the two, has less a specific content or meaning than a twofold function: self-identification and self-affirmation. Rather than pick out and esteem or recommend any particular quality, habit, or trait, 'good' simply indicates 'I' or 'we' while simultaneously expressing admiration and respect for the subject or subjects who think, speak, or write it. In short, the word is something like a term of endearment or praise that noble men apply to themselves. These nobles may well ground their self-regard in their possession of this or that property or set of properties, yet it is not the properties that give value to the men but rather the other way round."

23 David B. Allison, Reading the New Nietzsche, The Birth of Tragedy, The Gay Science, Thus Spoke Zarathustra, and On the Genealogy of Morals, 203.

24 Mark Anderson, Plato and Nietzsche, Their Philosophical Art, 143-144.

25 Peter Bornedal dalam The Surface and the Abyss: Nietzsche as Philosopher of Mind and Knowledge, 364, mengatakan, "Gradually, however, the words themselves acquire something tantamount to as 'soul'. As values, they will be inverted: they will no longer refer to appearances, but to hidden essences. 'Good' will in later developments refer to the unselfish and non-egoistic action; a reference that culminates in Kant's dictum of the 'good will' that is good 'initself'-no longer 'good' as appearance.'

26 Mark Anderson dalam Plato and Nietzsche, Their Philosophical Art, 146, mengatakan bahwa kaum budak dapat melakukan pemberontakan ini karena mereka memiliki kehendak bebas (free will). Lih. GM I §10, §11.

27 Tracy B. Strong dalam Friedrich Nietzsche and the Politics of Transfiguration, Expanded Edition, London: University of California Press, 1988, 242, mengatakan bahwa pembalikan nilai juga dapat dipahami dari ciri pernyataan masingmasing. Moral tuan akan mengatakan, "Aku baik, maka kamu buruk", sedangkan moral budak akan mengatakan, "Kamu menindas aku sehingga kamu jahat, maka aku baik." Tampak ada hubungan kausalitas antara moral tuan dan moral budak yang ditandai dengan kata penghubung "maka". Bagian kedua dari pernyataan moral tuan berkonotasi "negatif". Namun, pernyataan moral tuan ini tidak mengandung perbandingan karena kesadaran tuan dalam dirinya tidak bergantung pada pembanding dari luar. Nietzsche mengatakan, "Nilai buruk dari asal-usul moral tuan ... adalah sebuah hasil dari sebuah tindakan, sebuah efek samping, sebuah bayangan kontras...." (GM I §11, GM II §785). Premis pernyataan ini positif dan afirmatif. Itulah mengapa Nietzsche mengatakan bahwa tidak ada kemunduran yang lahir dari tanah kaum tuan karena tidak ada benih busuk yang tumbuh di dalamnya. Adapun pernyataan moral budak menunjukkan efek negasi dari negasi, artinya menyangkal sesuatu dari luar dan menerima diri yang menolak penderitaan yang mereka terima. Moral budak selalu menerima penderitaan dalam hidup. Apabila mereka menolak penderitaan, artinya mereka hanya menegaskan penderitaan itu sendiri. Strong mengatakan, "The moral sense of self 
and the identity of the slave become in effect a negation of a negation, and consist of denying something that effects one from without, and then asserting one's identity as the opposite of that by which one is afflicted" (Strong, ibid.)

28 David B. Allison, Reading the New Nietzsche, The Birth of Tragedy, The Gay Science, Thus Spoke Zarathustra, and On the Genealogy of Morals, 204-205. Bdk. Mark Anderson, Plato and Nietzsche, Their Philosophical Art, 145. Lih. On the Genealogy of Morals I§11.

29 Mark Anderson, Plato and Nietzsche, Their Philosophical Art, 145. Lih. On the Genealogy of Morals I 44.

30 Mark Anderson dalam Plato and Nietzsche, Their Philosophical Art, 145, mengatakan, "It takes no great leap of imagination to picture these men as having been discontented with their status and the social, political, existential, and even the psychological consequences of that status. Discontented, but with no means to improve their lot. Having no productive outlet for their dissatisfaction, they internalized it, and the roiling blend of their unhappiness and impotence emitted fumes of rage, which in some men were so potent, so heady, so in toxicating that the men in their frenzy became for one horrible moment creative." Anderson menambahkan bahwa kaum budak akan meluapkan omongan rendahan mereka dengan mengatakan, "Aku tidak bahagia. Aku sengsara. Aku menderita. Mengapa? Harus ada orang yang disalahkan. Lihat, orang itu lebih baik dari aku. Dia tampak begitu ceria dan tersenyum bahagia. Oh, ini semua tidak adil. Hidupku tidak setara dengan dia. Oh, dia yang harus disalahkan atas keadaanku. Dia yang telah melakukan ini semua kepadaku. Dia yang melukaiku. Dia kejam, bengis, keji—dia jahat" (Anderson, ibid.)

31 David B. Allison, Reading the New Nietzsche, The Birth of Tragedy, The Gay Science, Thus Spoke Zarathustra, and On the Genealogy of Morals, 204, mengatakan, "At first, the opposition and revolt would appear to call for a political, if not military, means of resolution, since the lower classes traditionally outnumber the aristocratic class. But Nietzsche argues that, since the lower classes are initially powerless, the revolt must, at least at the start, be one of a psychological-moral variety (i.e., a substitute for real action)."

32 David B. Allison, Reading the New Nietzsche, The Birth of Tragedy, The Gay Science, Thus Spoke Zarathustra, and On the Genealogy of Morals, 204.

33 David B. Allison, Reading the New Nietzsche, The Birth of Tragedy, The Gay Science, Thus Spoke Zarathustra, and On the Genealogy of Morals, 204.

34 David B. Allison dalam Reading the New Nietzsche, The Birth of Tragedy, The Gay Science, Thus Spoke Zarathustra, and On the Genealogy of Morals, 205, mengatakan, "In time, the classical world of Greece and Rome passes over to the medieval world of feudal, aristocratic regimes, which in turn-given the Christian doctrine of the equality of all souls before God-becomes transformed through the revolutions and liberation movements, beginning in the eighteenth century, into modern, democratic societies. Ultimately, the 'slave revolt' succeeds, historically and politically. Yet the values we have inherited in the process of this two-thousand-year revolt remain strikingly problematic for Nietzsche."

35 Maudemarie Clark dalam Friedrich Nietzsche, On the Genealogy of Morality, (trans. and ed.) Maudemarie Clark and Alan J. Swensen, Indiana: Hackett Publishing Company, Inc. 1998, xxix-xxx.

36 David B. Allison, Reading the New Nietzsche, The Birth of Tragedy, The Gay Science, Thus Spoke Zarathustra, and On the Genealogy of Morals, 204-205. Bdk. Daniel Conway, Nietzsche's On the Genealogy of Morals, A Reader's Guide, Cornwall: Continuum, 2008, 41.

37 David B. Allison, Reading the New Nietzsche, The Birth of Tragedy, The Gay Science, Thus Spoke Zarathustra, and On the Genealogy of Morals, 205.

38 Friedrich Nietzsche, On the Genealogy of Morality, (trans. and ed.) Maudemarie Clark and Alan J. Swensen, Indiana: Hackett Publishing Company, Inc. 1998, 19.

39 David B. Allison, Reading the New Nietzsche, The Birth of Tragedy, The Gay Science, Thus Spoke Zarathustra, and On the Genealogy of Morals, 205.

40 David B. Allison, Reading the New Nietzsche, The Birth of Tragedy, The Gay Science, Thus Spoke Zarathustra, and On the Genealogy of Morals, 206.

41 David B. Allison, Reading the New Nietzsche, The Birth of Tragedy, The Gay Science, Thus Spoke Zarathustra, and On the Genealogy of Morals, 206.

42 Bdk. Mark Anderson, Plato and Nietzsche, Their Philosophical Art, 143.

43 David B. Allison, Reading the New Nietzsche, The Birth of Tragedy, The Gay Science, Thus Spoke Zarathustra, and On the Genealogy of Morals, 207.

44 David B. Allison, Reading the New Nietzsche, The Birth of Tragedy, The Gay Science, Thus Spoke Zarathustra, and On the Genealogy of Morals, 207.

45 David B. Allison, Reading the New Nietzsche, The Birth of Tragedy, The Gay Science, Thus Spoke Zarathustra, and On the Genealogy of Morals, 207.

46 Friedrich Nietzsche, On the Genealogy of Morality, (trans. and ed.) Maudemarie Clark and Alan J. Swensen, 19.

47 Tracy B. Strong dalam Friedrich Nietzsche and the Politics of Transfiguration, 245-246.

48 Friedrich Nietzsche, On the Genealogy of Morality, (trans. and ed.) Maudemarie Clark and Alan J. Swensen, 19.

49 Peter Bornedal, The Surface and the Abyss: Nietzsche as Philosopher of Mind and Knowledge, 364.

50 Peter Bornedal dalam The Surface and the Abyss: Nietzsche as Philosopher of Mind and Knowledge, 364-365, mengatakan, "In both of these assumptions, it is taken for granted that in every action there is a doer before there is 
a deed, that is, a conscious and responsible agent. Qua this doer, depth has been applied to the individual; it is the supposed doer that is responsible for the action of the individual."

51 Peter Bornedal, The Surface and the Abyss: Nietzsche as Philosopher of Mind and Knowledge, 365.

52 Peter Bornedal, The Surface and the Abyss: Nietzsche as Philosopher of Mind and Knowledge, 365.

53 Peter Bornedal, The Surface and the Abyss: Nietzsche as Philosopher of Mind and Knowledge, 365-366.

54 Peter Bornedal dalam The Surface and the Abyss: Nietzsche as Philosopher of Mind and Knowledge, 366, mengatakan, "In his writings, Nietzsche overwhelmingly describes the 'noble' as he. We have so far been so lax as to follow Nietzsche's precedent; but it is now the place to emphasize that insofar as the 'noble' emerges as a figure and an economy, the 'noble' is typically feminine."

55 Peter Bornedal, The Surface and the Abyss: Nietzsche as Philosopher of Mind and Knowledge, 366.

56 Peter Bornedal, The Surface and the Abyss: Nietzsche as Philosopher of Mind and Knowledge, 366.

57 Peter Bornedal dalam The Surface and the Abyss: Nietzsche as Philosopher of Mind and Knowledge, 366-367, mengatakan bahwa hubungan antara maskulinitas dan feminitas dalam pemikiran Nietzsche bersifat matriarkal, sedangkan dalam psikoanalisis Freud, hubungan tersebut bersifat patriarkal. Dalam psikoanalisis, Bornedal menyatakan, "man has what a woman lacks, a penis, which gives ris not only to the notorious 'penis-envy' in women, but equally notoriously also to her sense of inferiority, and her incapacity to engage in grand projects. She has no fear of losing what she has already lost - has no 'castration-anxiety'-and has therefore no more motivation to engage in projects much more beyond the concerns of the household” (Bornedal, op. cit., 367).

58 Peter Bornedal, The Surface and the Abyss: Nietzsche as Philosopher of Mind and Knowledge, 367.

59 Peter Bornedal, The Surface and the Abyss: Nietzsche as Philosopher of Mind and Knowledge, 368.

60 Peter Bornedal dalam The Surface and the Abyss: Nietzsche as Philosopher of Mind and Knowledge, 368, mengatakan, "In this quotation, the opaqueness of the woman becomes total when she die-Augen-über-sich-geschlossen-haltenby virtue of her delicacy and because she knows the utility of innocence. Now she does not even dissimulate any longer, granted that dissimulation presupposes a conscious operation in which the subject knows that she is dissimulating (implying that the subject would know the truth of her operation, namely that there is no truth). Instead, the woman closes her eyes to her lack of truth, lack of 'content' or 'essence.' Not only does man overestimate woman, she overestimates herself as well."

61 Peter Bornedal, The Surface and the Abyss: Nietzsche as Philosopher of Mind and Knowledge, 368-369.

62 Peter Bornedal dalam The Surface and the Abyss: Nietzsche as Philosopher of Mind and Knowledge, 370, mengatakan bahwa selain menjadi obyek imajiner, wanita juga menjadi contoh model metafisika par excellence. Namun, metafisika Nietzsche ini berbeda dengan metafisika Aristoteles tentang motor imobil, yakni penggerak yang dirinya sendiri tidak bergerak. Jika motor imobil dianggap sebagai obyek dari segala hasrat, keinginan, dan cinta, wanita dalam pemikiran Nietzsche bukanlah obyek, melainkan hanya sebagai proyeksi. Bornedal menyatakan, "At the culmination of this logic, she would have become a purely imaginary object of desire. From her emptiness and lack, she 'refashions' in the imaginary herself as Truth. She performs what we call, a 'good reaction' to her empty core. Women becomes the model-example of a metaphysical operation par excellence, operating in a fashion not fundamentally different from Aristotle's 'unmoved mover'; the Aristotelian god that moves only as a final cause, i.e., only as an object of desire and 'love'-except that in Nietzsche, in contrast to Aristotle, the object is fundamentally absent; or, is merely a projection" (Bornedal, ibid.)

63 Peter Bornedal dalam The Surface and the Abyss: Nietzsche as Philosopher of Mind and Knowledge, 372, membandingkan ketaksadaran dalam pemikiran Nietzsche dengan Freud. Freud mengatakan bahwa ketidaksadaran (Id) akan diatasi oleh kesadaran ego (I). Sementara ketidaksadaran dalam pemikiran Nietzshce, Bornedal menyatakan, "If Freud prescribed, Wo Es war soll Ich werden, Nietzsche response could have been the brief, forget it/Id!" (Bornedal, ibid.)

64 Penulis menerjemahkan kata reaction menjadi responsif untuk membedakannya dengan reaktif. Kata responsif dan reaktif sama-sama merupakan tanggapan atau aksi atas suatu opini atau peristiwa (https://kbbi.kemdikbud.go.id/responsif dan https://kbbi.kemdikbud.go.id/reaktif) Yang membedakan keduanya adalah bahwa responsif memerlukan pertimbangan atau refleksi sehingga berkonotasi positif (lexico.com/definition/responsive). Adapun reaktif merupakan tanggapan spontan tanpa pertimbangan (lexico.com/definition/reactive). Kata reaksi atau reaktif ini, menurut penulis, lebih tepat digunakan untuk merujuk moral budak.

65 Peter Bornedal dalam The Surface and the Abyss: Nietzsche as Philosopher of Mind and Knowledge, 372, mengatakan, "The master, the noble, however, actively forgets this lack, and acts out a power, which fundamentally he/she does not have. Active forgetfulness is to forget nothing (i.e., that one is nothing). [...] Active forgetfulness is therefore what we describe as a good reaction to the essential absence in the subject; as such, it 'touches' an empty core."

66 Peter Bornedal, The Surface and the Abyss: Nietzsche as Philosopher of Mind and Knowledge, 372.

67 Peter Bornedal, The Surface and the Abyss: Nietzsche as Philosopher of Mind and Knowledge, 373.

68 Hiperkateksis berasal dari kata kateksis yang berarti 'penimbunan energi psikis yang dipusatkan pada suatu pikiran, ingatan, atau perbuatan'. Hiperkateksis dengan demikian dapat diartikan sebagai penimbunan energi secara berlebihan pada suatu pikiran, ingatan, atau perbuatan. Sebaliknya, dekateksis berarti 'pelepasan energi pada suatu pikiran, 
ingatan, atau perbuatan' (K. Bertens, Psikoanalisis Sigmund Freud, Jakarta: Gramedia Pustaka Utama, 2016, 260). Helena Ragg-Kirby dalam Sigmund Freud, An Outline of Psychoanalysis, (trans. Helena Ragg-Kirby), London: Penguin Books, 2003, xxiv, mengatakan bahwa kateksis yang berasal dari kata Jerman Besetzung (nomina) dan besetzen (verba) memiliki arti 'penanaman energi pada suatu perbuatan. Penulis mengikuti definisi keduanya, tetapi dalam beberapa kesempatan penulis menggunakan daya sebagai ganti atas energi.

69 Peter Bornedal, The Surface and the Abyss: Nietzsche as Philosopher of Mind and Knowledge, 373. Bornedal mengutip HAH 105, KSA 3, hlm. 92 untuk menegaskan tipe manusia budak: "For all their apparent egoism, most people do nothing for their ego but only for the phantom of their ego that has been formed in the heads of those around them and communicated back to them - as a result of which everybody lives in a mist of impersonal, semi personal opinions and arbitrary, and, as it were, poetic evaluations, each one always in the head of the other, and that head in turn in other heads: a wonderful world of phantasms, that yet manages to appear so sober!"

70 Peter Bornedal, The Surface and the Abyss: Nietzsche as Philosopher of Mind and Knowledge, 375-376.

71 Peter Bornedal, The Surface and the Abyss: Nietzsche as Philosopher of Mind and Knowledge, 375.

72 Peter Bornedal dalam The Surface and the Abyss: Nietzsche as Philosopher of Mind and Knowledge, 376, mengatakan, "Since the nobles hyper-cathect their inside, they become fountains of energy; energy that needs an outlet. The spontaneous deed-the deed that cannot but be acted out-springs from this overflow. This deed is pure activity; it springs unhindered from the inside to the outside; it is inspirational in the purest sense-without having been mediated through a divine will, as in Romanticism."

73 Peter Bornedal, The Surface and the Abyss: Nietzsche as Philosopher of Mind and Knowledge, 377.

74 Peter Bornedal dalam The Surface and the Abyss: Nietzsche as Philosopher of Mind and Knowledge, 377, mengatakan bahwa manusia budak dalam konfigurasi agresif ini mengalami apa yang disebut dengan ego yang terbelah. Ia menyatakan, "In his characterizations of the servile configuration, Nietzsche is describing an ego-split. In the figures of noble and slave, we have, respectively, a first-case scenario in which there is harmony between the ego and its instinctual reservoir - a noble and 'full' subject, and a second-case scenario, where ego deepens, producing a cavity within the subject that finally splits away from the subject, implying that the resulting 'vacuous' and 'confused' subject is obedient to whatever is filled into this new extension of itself."

75 Peter Bornedal dalam The Surface and the Abyss: Nietzsche as Philosopher of Mind and Knowledge, 377, mengatakan, "Thus, it is accurate to say that the slave creates within himself a crypt; a hollow and secret space where he can cultivate all kinds of poisonous plants. A further consequence of the creation of this crypt self is that the slave can now withdraw himself to this hollow and secret space in order to ruminate, calculate, reflect on consequences of potential actions not yet carried out."

76 Peter Bornedal, The Surface and the Abyss: Nietzsche as Philosopher of Mind and Knowledge, 378.

77 Peter Bornedal, The Surface and the Abyss: Nietzsche as Philosopher of Mind and Knowledge, 379.

78 Peter Bornedal, The Surface and the Abyss: Nietzsche as Philosopher of Mind and Knowledge, 379.

79 Peter Bornedal, The Surface and the Abyss: Nietzsche as Philosopher of Mind and Knowledge, 380.

80 Peter Bornedal dalam The Surface and the Abyss: Nietzsche as Philosopher of Mind and Knowledge, 380, mengutip penggalan GM II $\S 1$ untuk menjelaskan tentang pelupaan: "Forgetfulness is no mere vis inertia as the superficial imagine; it is rather an active and, in the strictest sense, positive capacity for repression. It is responsible for the fact that what we see and experience enters our consciousness as little, while we are digesting it, as does the thousandfold process related to physical - so called 'incorporation'. To close the doors and windows of consciousness for a while; to remain undisturbed by the noise and struggle of our underworld of utility organs working with and against one another; a little quietness, a little tabula rasa of the consciousness, to make room for new things, [...] that is the purpose of active forgetfulness, which is like a doorkeeper, a preserver of psychic order, repose, and etiquette. So it becomes immediately obvious that there would be no happiness, no cheerfulness, no hope, no pride, no present, without forgetfulness."

81 Peter Bornedal, The Surface and the Abyss: Nietzsche as Philosopher of Mind and Knowledge, 380.

82 Peter Bornedal, The Surface and the Abyss: Nietzsche as Philosopher of Mind and Knowledge, 383-384.

83 Peter Bornedal, The Surface and the Abyss: Nietzsche as Philosopher of Mind and Knowledge, 383-384.

84 Peter Bornedal dalam The Surface and the Abyss: Nietzsche as Philosopher of Mind and Knowledge, 384-385, melihat ada tiga hal mengapa Nietzsche melakukan pembalikan itu: "First, one might simply dismiss Nietzsche's analysis, and pronounce Nietzsche guilty in yet another of his famous of infamous self-contradiction; case closed; the easiest solution, and also - if one dare say so-the most superficial. Secondly, one might argue that there is a significant distinction between the (forgetful) noble and the (memorizing) sovereign and correspondingly, between the (memorizing) slave and the (forgetful) windbag\}. Nietzsche has in other words two master positions and two slave positions. [...] Thirdly, one might argue that there are different kinds of forgetfulness, as well as different kinds of memory, or that forgetfulness and memory are differently applied in different contexts."

85 Peter Bornedal, The Surface and the Abyss: Nietzsche as Philosopher of Mind and Knowledge, 385.

86 Peter Bornedal, The Surface and the Abyss: Nietzsche as Philosopher of Mind and Knowledge, 385.

87 Peter Bornedal, The Surface and the Abyss: Nietzsche as Philosopher of Mind and Knowledge, 386. 
88 Bornedal menyatakan bahwa dirinya memakai tafsiran Deleuze untuk menyebut "mengingat kata" dan "mengingat jejak" (Peter Bornedal, The Surface and the Abyss: Nietzsche as Philosopher of Mind and Knowledge, 386).

89 Peter Bornedal dalam The Surface and the Abyss: Nietzsche as Philosopher of Mind and Knowledge, 386, mengatakan, "The sovereign starts by imposing Law on himself and ends by imposing Law on society. Law is thus not a reaction of the slave, it is not revenge or ressentiment directed against the activity of the strong individual."

90 Peter Bornedal, The Surface and the Abyss: Nietzsche as Philosopher of Mind and Knowledge, 386.

91 Peter Bornedal, The Surface and the Abyss: Nietzsche as Philosopher of Mind and Knowledge, 386-387.

92 Peter Bornedal dalam The Surface and the Abyss: Nietzsche as Philosopher of Mind and Knowledge, 387, mengatakan, "Emerging form the human abyss of nothingness, justice becomes a universal standard measuring human action. The master applies this universal standard as much to himself as to fellow human beings."

93 Peter Bornedal, The Surface and the Abyss: Nietzsche as Philosopher of Mind and Knowledge, 389.

94 Peter Bornedal, The Surface and the Abyss: Nietzsche as Philosopher of Mind and Knowledge, 389-391.

95 Peter Bornedal, The Surface and the Abyss: Nietzsche as Philosopher of Mind and Knowledge, 389-391.

96 Peter Bornedal, The Surface and the Abyss: Nietzsche as Philosopher of Mind and Knowledge, 391.

97 Peter Bornedal, The Surface and the Abyss: Nietzsche as Philosopher of Mind and Knowledge, 391-392.

98 Peter Bornedal, The Surface and the Abyss: Nietzsche as Philosopher of Mind and Knowledge, 391.

99 Peter Bornedal dalam The Surface and the Abyss: Nietzsche as Philosopher of Mind and Knowledge, 393, mengatakan, "The 'sense of guilt' is re-directed from the external to the internal. From recognizing that one is indebted to a trading partner, the new 'sense of guilt' deepens, and is finally turned around and directed into the debtor's own self. All of sudden, one is indebted to an agency within oneself; an agency that still has the right to 'inflict every kind of indignity and torture upon the body, 'or more adequately, after the transition, the soul. Guilt/debt is internalized as aggression turned inwards. Transformed into this new psychological-moral concept, 'being guilty' is now self-aggression, and the penalty for 'being guilty' is no longer physical punishment, but spiritual self-punishment. The original 'enjoyable' and 'happy' cruelty is turned into forlorn and unhappy shame."

100 Peter Bornedal, The Surface and the Abyss: Nietzsche as Philosopher of Mind and Knowledge, 393.

101 Peter Bornedal, The Surface and the Abyss: Nietzsche as Philosopher of Mind and Knowledge, 394.

102 Peter Bornedal, The Surface and the Abyss: Nietzsche as Philosopher of Mind and Knowledge, 396.

${ }^{103}$ Peter Bornedal dalam The Surface and the Abyss: Nietzsche as Philosopher of Mind and Knowledge, 396-397, mengatakan bahwa Freud memiliki pandangan yang sama dengan Nietzsche. Menurut Freud, agresi berbalik ke dalam diri manusia karena peradaban/kebudayaan melarang manusia melepaskan agresi ke luar dirinya. Ketika diinternalisasikan, agresi super-ego ini kemudian berbalik menyerang ego. Dengan "bantuan" super-ego inilah, masyarakat dapat melakukan pengawasan lebih efisien. Masyarakat tidak perlu bersusah payah mengawasi anggotanya karena dalam diri anggotanya sudah ada "pengawas" yang mengawasi diri sendiri. Bornedal mengutip Freud demikian: "What means does civilization [Kultur] employ in order to inhibit the aggressiveness which opposes it, to make it harmless, to get rid of it. [...] What happens in the [individual] to render his desire for aggression innocuous? Something very remarkable, [...] his aggressiveness is introjected, internalized [Verinnerlicht]; it is, in point of fact, sent back to where it came from - that is, it is directed towards his own ego. There it is taken over by a portion of the ego, which sets itself over against the rest of the ego as super-ego, and which now, in the form of 'conscience' is ready to put into action against the ego the same harsh aggressiveness that the ego would have liked to satisfy upon extraneous individuals, the tension between the harsh super-ego and the ego that is subjected to it, is called by us the sense of guilt [Schuldbewußtsein], it expresses itself as need for punishment. Civilization, therefore, obtains mastery over the individual's dangerous desire for aggression weakening and disarming it and by setting up an agency within him to watch over it" (Bornedal, op. cit., 397).

${ }^{104}$ Peter Bornedal, The Surface and the Abyss: Nietzsche as Philosopher of Mind and Knowledge, 399.

105 Peter Bornedal, The Surface and the Abyss: Nietzsche as Philosopher of Mind and Knowledge, 399.

106 Bdk. On the Genealogy of Morals II $\S 3$.

107 Alexander Nehamas, Nietzsche Life as Literature, Massachusetts: Harvard University Press, 1985, 207. Bdk. GM I $\S 10$.

108 Alexander Nehamas, Nietzsche Life as Literature, 1985, 210. Lih. GS §371, GM I 77 dan $\S 8$.

109 Alexander Nehamas, Nietzsche Life as Literature, 1985, 211.

110 Alexander Nehamas dalam Nietzsche Life as Literature, 1985, 211, mengatakan, "It does not simply include evil among the necessary aspects of the world. It does not simply claim that in order to possess any good qualities one must possess evil qualities as well. It actually denies that the distinction between good and evil can be made at all, and suggests that the very same quality that is considered evil from one perspective may at least as accurately be characterized as good from another."

111 Alexander Nehamas, Nietzsche Life as Literature, 216.

112 Alexander Nehamas, Nietzsche Life as Literature, 216.

113 Alexander Nehamas dalam Nietzsche Life as Literature, 218, dengan mengutip BGE $\$ 230$, mengatakan, "The physical cruelty of the nobles results from a drive that should not be eliminated in itself; on the contrary, the drive is to be maintained and its expression refined into that sublime inclination of the seeker after knowledge who insists on 
profundity, multiplicity, and thoroughness, with a will which is a kind of cruelty of the intellectual conscience and taste. All courageous thinkers will recognize this in themselves [...] They will say: 'There is something cruel in the inclination of my spirit;' let the virtuous and kindly try to talk them out of that! Indeed, it would sound nicer if we were said, whispered, reputed to be distinguished not by cruelty but by 'extravagant honesty,' we free, very free spirits - and perhaps that will actually be our posthumous reputation."

114 Peter Bornedal, The Surface and the Abyss: Nietzsche as Philosopher of Mind and Knowledge, 400.

115 Bdk. Ted Sadler, Truth and Redemption, Critique of the Postmodernist Nietzsche, London: The Athlone Press, 1995, 73.

116 Peter Bornedal dalam The Surface and the Abyss: Nietzsche as Philosopher of Mind and Knowledge, 400, menyatakan, "First, we must always remember that to Nietzsche, the distinction between good and evil is never as solid as we tend to think. It is, as all oppositions, a vibrating opposition."

117 Peter Bornedal, The Surface and the Abyss: Nietzsche as Philosopher of Mind and Knowledge, 400-401, mengatakan, "In the good/evil position, the two positions are complementary. There may be anthropological reasons why it is impossible in the human being to eradicate 'evil,' but there also pragmatic-linguistic reasons. In the attempt to eradicate one of the positions, one destroys the entire value-system. That is, 'good' does not exist without a preknowledge of what is 'evil,' and vice versa, 'evil' does not exist without a pre-knowledge of the 'good. ,'

118 Peter Bornedal dalam The Surface and the Abyss: Nietzsche as Philosopher of Mind and Knowledge, 401, mengatakan, "Thus, our good/evil distinction is an unstable and relative opposition, which in touch with the original process it signifies, consists of interrelated and co-dependent positions. The so-called 'good' may turn out to be a mere euphemistic re-labelling of something originally 'evil.' What has happened is that at one point a 'semantic cluster' is labelled good, and instantly it splits away from the greater cluster it was once a part of. As an identifiable split-off formation ('identifiable' thanks to the label 'good'), the new semantic cluster, which is never more than a different degree of the same, now sees the old cluster as its opposite, as evil ("it is easier to think opposition, than gradation"). As such, the opposition 'good' versus 'evil' may well be of the same origin, and the good will of the self-righteous may easily be merely a refined and sublimated derivation of something that originally was, perhaps still is, annexed to original cruelty."

${ }^{119}$ Peter Bornedal, The Surface and the Abyss: Nietzsche as Philosopher of Mind and Knowledge, 401.

${ }^{120}$ Peter Bornedal, The Surface and the Abyss: Nietzsche as Philosopher of Mind and Knowledge, 401.

${ }^{121}$ Peter Bornedal, The Surface and the Abyss: Nietzsche as Philosopher of Mind and Knowledge, 401-402.

122 Peter Bornedal, The Surface and the Abyss: Nietzsche as Philosopher of Mind and Knowledge, 402. 